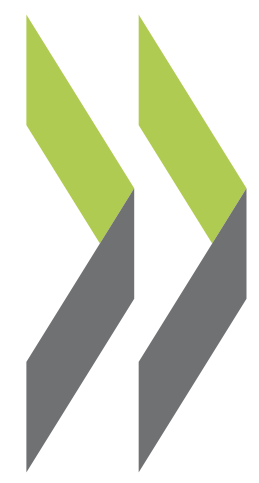

OECD Economics Department Working Papers No. 1322

Strengthening competition in network sectors and the internal market Corinne Luu

in Canada 
Organisation de Coopération et de Développement Économiques

Organisation for Economic Co-operation and Development

01-Aug-2016

ECONOMICS DEPARTMENT

English - Or. English

STRENGTHENING COMPETITION IN NETWORK SECTORS AND THE INTERNAL MARKET IN CANADA

ECONOMICS DEPARTMENT WORKING PAPERS No. 1322

By Corinne Luu

OECD Working Papers should not be reported as representing the official views of the OECD or of its member countries. The opinions expressed and arguments employed are those of the author $(s)$.

Authorised for publication by Robert Ford, Deputy Director, Country Studies Branch, Economics Department

All Economics Department Working Papers are available at www.oecd.org/eco/workingpapers

JT03399575

Complete document available on OLIS in its original format

This document and any map included herein are without prejudice to the status of or sovereignty over any territory, to the delimitation of international frontiers and boundaries and to the name of any territory, city or area. 
OECD Working Papers should not be reported as representing the official views of the OECD or of its member countries. The opinions expressed and arguments employed are those of the author(s).

Working Papers describe preliminary results or research in progress by the author(s) and are published to stimulate discussion on a broad range of issues on which the OECD works.

Comments on Working Papers are welcomed, and may be sent to OECD Economics Department, 2 rue André Pascal, 75775 Paris Cedex 16, France, or by e-mail to eco.contact@oecd.org.

All Economics Department Working Papers are available at www.oecd.org/eco/workingpapers.

This document and any map included herein are without prejudice to the status of or sovereignty over any territory, to the delimitation of international frontiers and boundaries and to the name of any territory, city or area.

The statistical data for Israel are supplied by and under the responsibility of the relevant Israeli authorities. The use of such data by the OECD is without prejudice to the status of the Golan Heights, East Jerusalem and Israeli settlements in the West Bank under the terms of international law.

Latvia was not an OECD Member at the time of preparation of this publication. Accordingly, Latvia does not appear in the list of OECD Members and is not included in the zone aggregates.

\section{(C) OECD (2016)}

You can copy, download or print OECD content for your own use, and you can include excerpts from OECD publications, databases and multimedia products in your own documents, presentations, blogs, websites and teaching materials, provided that suitable acknowledgment of OECD as source and copyright owner is given. All requests for commercial use and translation rights should be submitted to rights@oecd.org 


\section{ABSTRACT/RÉSUMÉ \\ Strengthening competition in network sectors and the internal market in Canada}

Canada's productivity performance has lagged that of many other OECD countries, despite some improvement in recent years. One measure to enhance overall efficiency would be to strengthen competition on the domestic market to drive future multi-factor productivity improvements. The potential gains are large: about a half a percent per year over a fairly long horizon. This paper focuses on increasing competition in network sectors, including energy, telecommunication services and broadcasting, and transportation, which are key inputs to production in the broader economy. Improving regulatory conditions, efficiency and/or cost competitiveness could yield more productive outcomes in these sectors, as well as in downstream industries. Competition could also be increased by lowering barriers to interprovincial trade and the movement of labour, which act to fragment Canada's already small domestic market. To this end, reforms of the Agreement on Internal Trade and measures to reduce sectoral barriers to trade are also discussed.

This Working Paper relates to the 2016 OECD Economic Survey of Canada (www.oecd.org/eco/surveys/economic-survey-canada.htm)

JEL classification codes: J44, L1, L3, L5, L66, L9, O43, Q18

Keywords: competition, network industries, integration, regulation, Canada, productivity

$* * * * * * * *$

\section{Concurrence dans les industries de réseau et renforcement du marché intérieur au Canada}

La productivité canadienne est inférieure à celle de nombreux pays de l'OCDE malgré quelques progrès ces dernières années. Il serait possible d'accroître l'efficience globale en renforçant la concurrence sur le marché intérieur afin de favoriser les futurs gains de productivité globale. Ces gains sont importants, de l'ordre d'un demi pour cent par an sur une période plutôt longue. Ce document porte principalement sur l'intensification de la concurrence dans les industries de réseau, comme l'énergie, les télécommunications, la diffusion audiovisuelle et les transports, qui jouent un rôle essentiel dans le processus de production de l'ensemble de l'économie. L'amélioration de la réglementation, l'augmentation de l'efficience et/ou le renforcement de la compétitivité-coût pourraient accroitre la productivité dans ces secteurs, ainsi que dans les secteurs d'aval. La concurrence pourrait également être intensifiée par la réduction des obstacles aux échanges entre provinces et à la mobilité de la main-d'œuvre, qui fragmentent un marché intérieur déjà petit. Ce document examine donc également les réformes possibles de l'Accord sur le commerce intérieur et les mesures visant à réduire les obstacles sectoriels aux échanges.

Ce Document de travail se rapporte à l'Étude économique de l'OCDE du Canada 2016 (www.oecd.org/fr/eco/etudes/etude-economique-canada.htm)

Classification JEL: J44, L1, L3, L5, L66, L9, O43, Q18

Mots clef: concurrence, industrie de réseau, intégration, règlementation, Canada, productivité 


\section{TABLE OF CONTENTS}

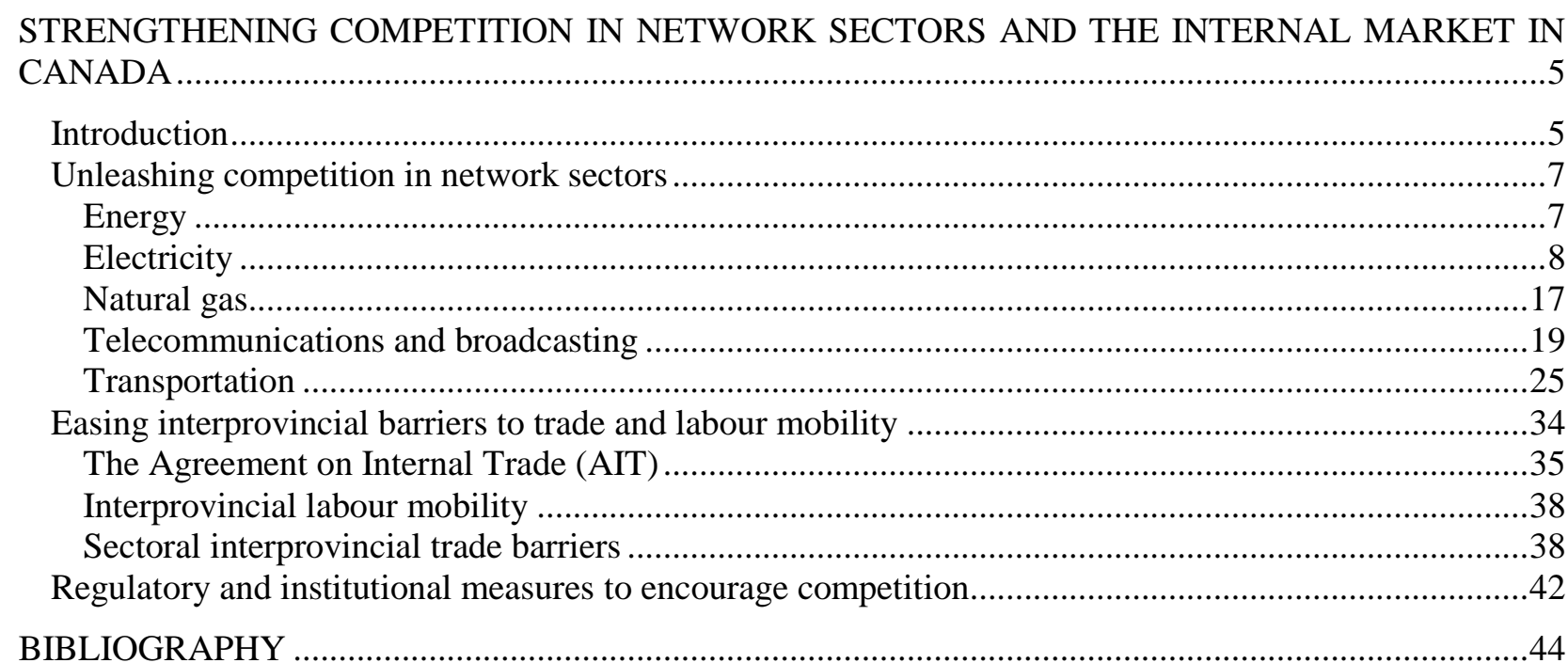

\section{Tables}

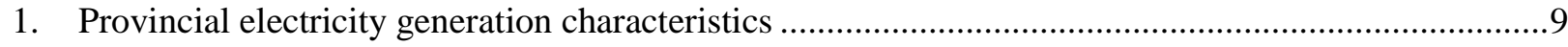

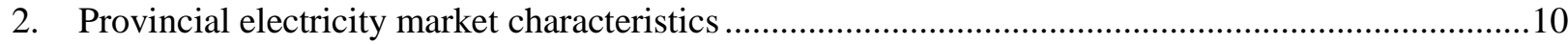

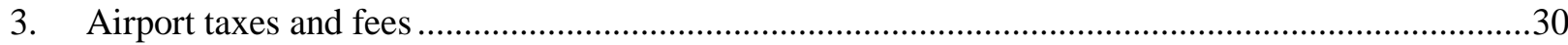

4. Regulations to facilitate competition in the Canadian rail sector ....................................................32

\section{Figures}

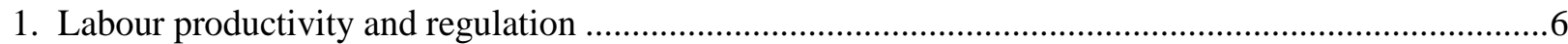

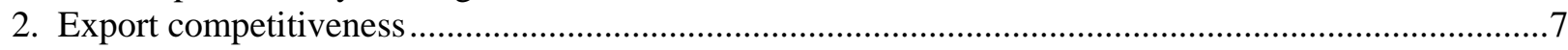

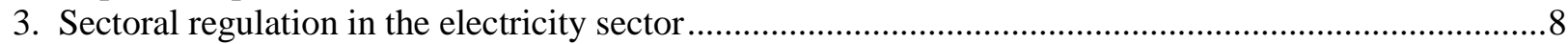

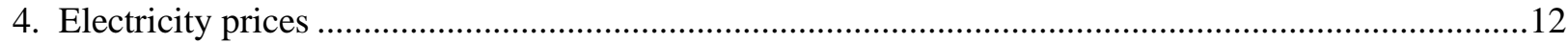

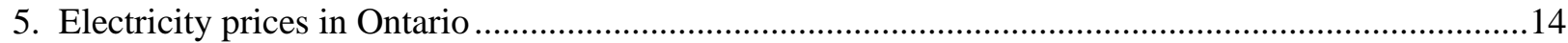

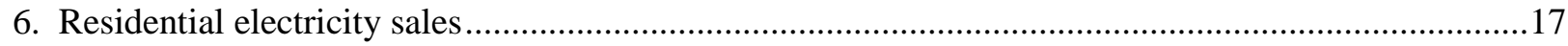

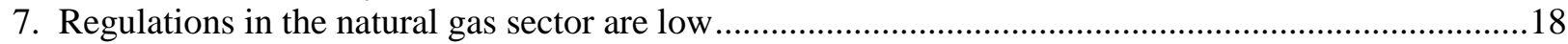

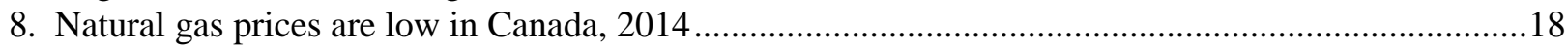

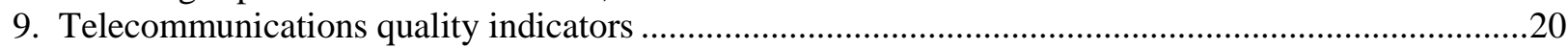

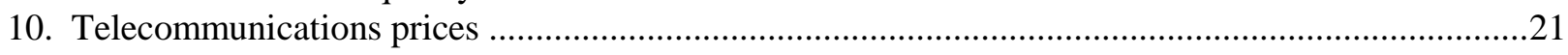

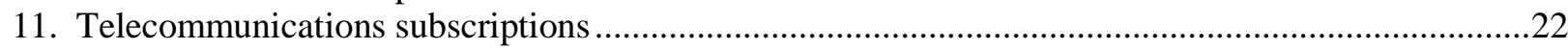

12. Foreign entry restrictions in telecommunications are high in Canada ..........................................24

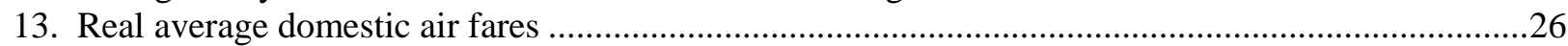

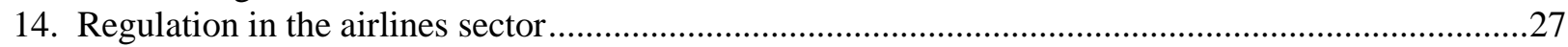

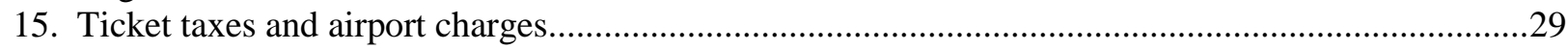

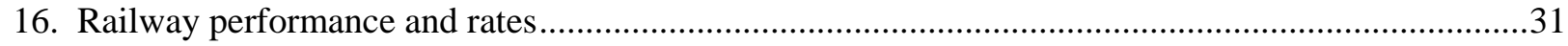

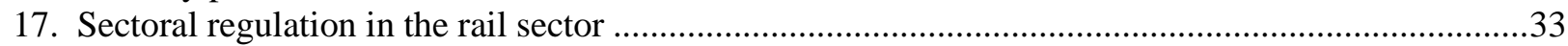

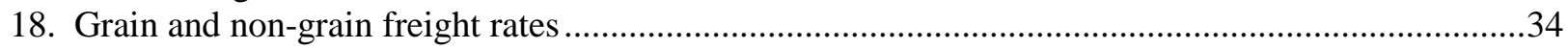

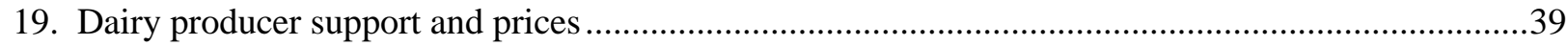

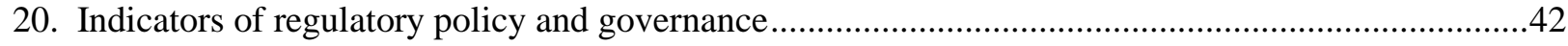

\section{Boxes}

Box 1. Electricity prices in Ontario and the Global Adjustment .........................................................14

Box 2. Summary of internal trade agreements outside of the AIT ......................................................36 
ECO/WKP(2016)46

\title{
STRENGTHENING COMPETITION IN NETWORK SECTORS AND THE INTERNAL MARKET IN CANADA
}

\author{
By Corinne $\mathrm{Luu}^{1}$
}

\section{Introduction}

Productivity in Canada has lagged that in the best performing countries, resulting in a gap in GDP per hour worked (Figure 1, Panel A). As productivity is ultimately the source of higher incomes and wider personal choices, addressing this shortfall is an important long-term policy challenge. The discipline provided by enhancing competition in the Canadian market place and strengthening the internal market can play a role in sustaining this productivity improvement.

Pro-competitive regulation can boost living standards, including by strengthening product safety and consumer protection. But poorly designed regulations lower productivity by weakening incentives to innovate, to adopt the technologies and organisational arrangements used by firms at the global productivity frontier and to limit reallocation of resources to the most productive firms (Andrews et al., 2015). One measure of regulations is the OECD's product market regulation indicator (PMR) (Koske et al., 2015). While overall PMRs in Canada are about as strict as the OECD average, adopting best practice (defined as the best three OECD countries' outcomes) would generate an estimated multi-factor productivity gain of some $3.2 \%$ (5.6\%) over a five-(ten-) year horizon. Moreover, PMRs in the network sectors of electricity, air transportation and telecommunication services are significantly more restrictive than those of best performers (Figure 1, Panel B). In these sectors labour productivity growth has lagged behind the broader economy (Panel C). Elsewhere, based on the OECD's STAN database, productivity outcomes are mixed, depending on the sector, though productivity weakness has been broad based.

Foreign direct investment restrictions, which are heavy in Canada, shrink access to capital, deter technology adoption and reduce competitive pressures and cost efficiency. Greater competition through eliminating foreign ownership restrictions in telecommunications, for example, could lower prices and increase access to fast, high-quality networks, raising business efficiency, better matching supply and demand in real time and enhancing the synchronisation of goods, services and payments in the supply chain. Lowering trade restrictions in telecommunications has been associated with more Internet subscriptions and may also boost exports of services and information-intensive goods (Nordås and Rouzet, 2015).

Competitive and efficient transportation services are crucial for Canada's integration into the global economy. For instance, cost-effective air transport services are important for trade in high-value products and time-sensitive goods. They also facilitate travel (and thereby well-being) and the tourism industry. Improving the regulatory environment and reducing foreign ownership restrictions in transportation could

\footnotetext{
${ }^{1}$ Corinne Luu is an economist in the Economics Department of the OECD; e-mail: corinne.luu@oecd.org. The author is thankful to Mark Baker (OECD Economics Department), Bert Brys (OECD Centre for Tax Policy and Administration), David Carey (OECD Economics Department), Robert Ford (OECD Economics Department), Massimo Geloso Grosso (OECD Trade and Agriculture Directorate), Michelle Harding (Centre for Tax Policy and Administration), Peter Jarrett (OECD Economics Department), Celine Kauffmann (OECD Public Governance and Territorial Developmment), Alain Lumbroso (OECD International Transport Forum), Sam Paltridge (Directorate for Science, Technology and Innovation), Alvaro Pereira (OECD Economics Department), Kurt Van Dender (Centre for Tax Policy and Administration) and Canadian government officials for their valuable comments and suggestions. This paper also benefited from technical background papers prepared by Mark Ronayne (Mark Ronayne Consulting). Special thanks are due to Isabelle Luong (OECD Economics Department) for excellent statistical assistance and Dacil Kurzweg (OECD Economics Department) and Amelia Godber (OECD Economics Department) for technical preparation.
} 
lead to an expansion of exports, strengthening export performance (exports relative to foreign market growth), which has deteriorated significantly in recent years (Figure 2, Panel A). These services are a significant input into industrial exports and tend to play a somewhat larger role in Canada than in many other OECD countries (Panel B), probably reflecting its geographical size and export composition. According to Hummels and Schaur (2013), an additional day in transit is equivalent to an ad valorem tariff of 0.6 to $2.1 \%$, depending how time-sensitive the product is.

Figure 1. Labour productivity and regulation

\section{A. The gap in labour productivity persists}

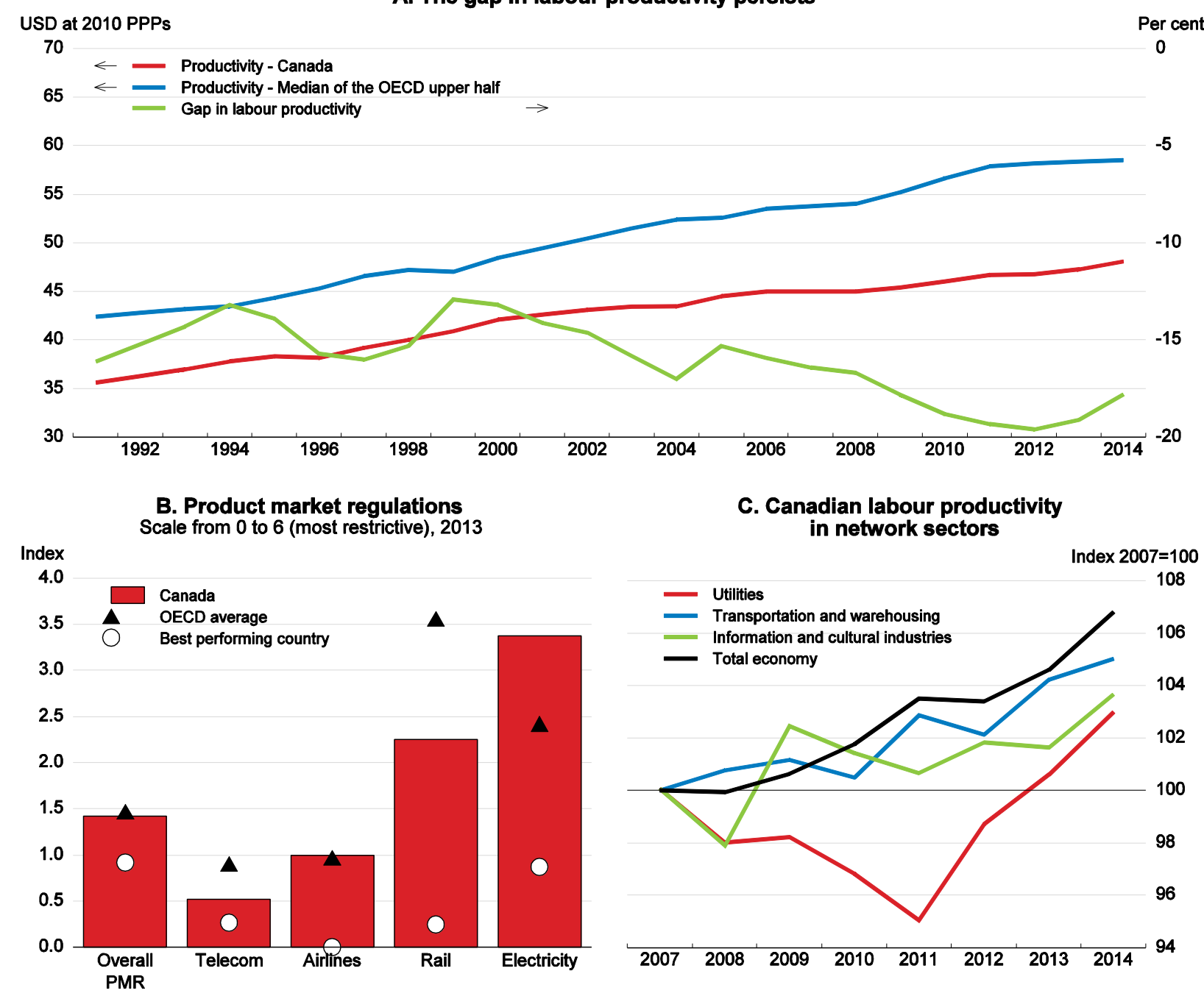

Source: Statistics Canada; OECD, National Accounts database, Productivity database and Product Market Regulation database. 
Figure 2. Export competitiveness

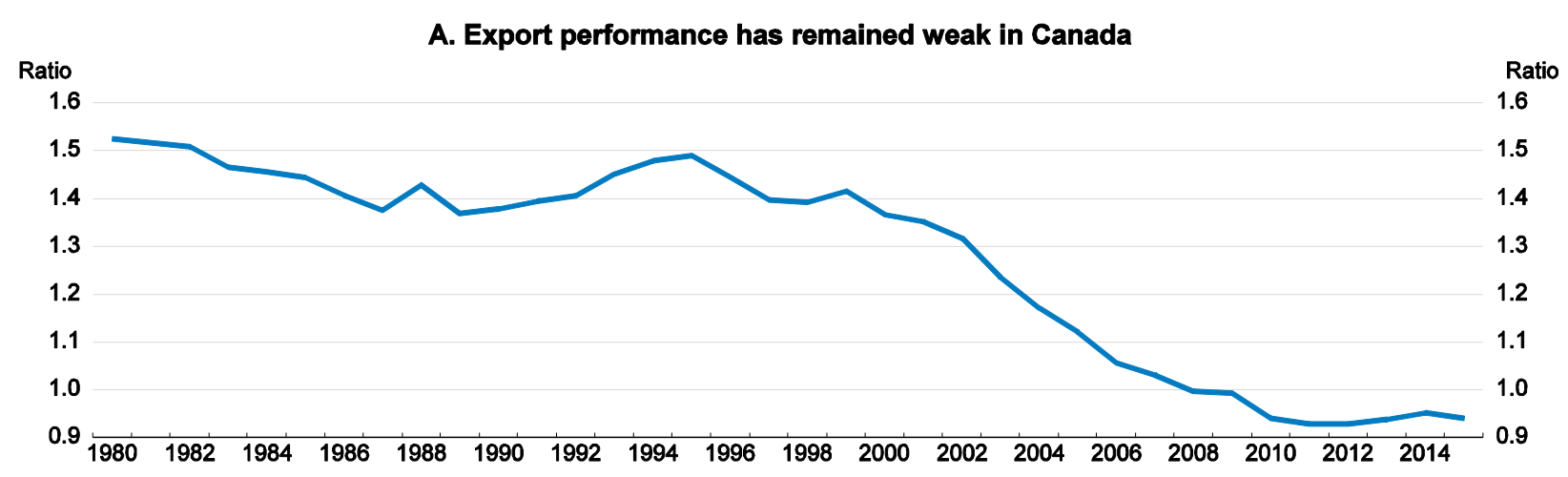

B. Domestically-produced value-added share of transportation and storage in gross industrial exports, 2011

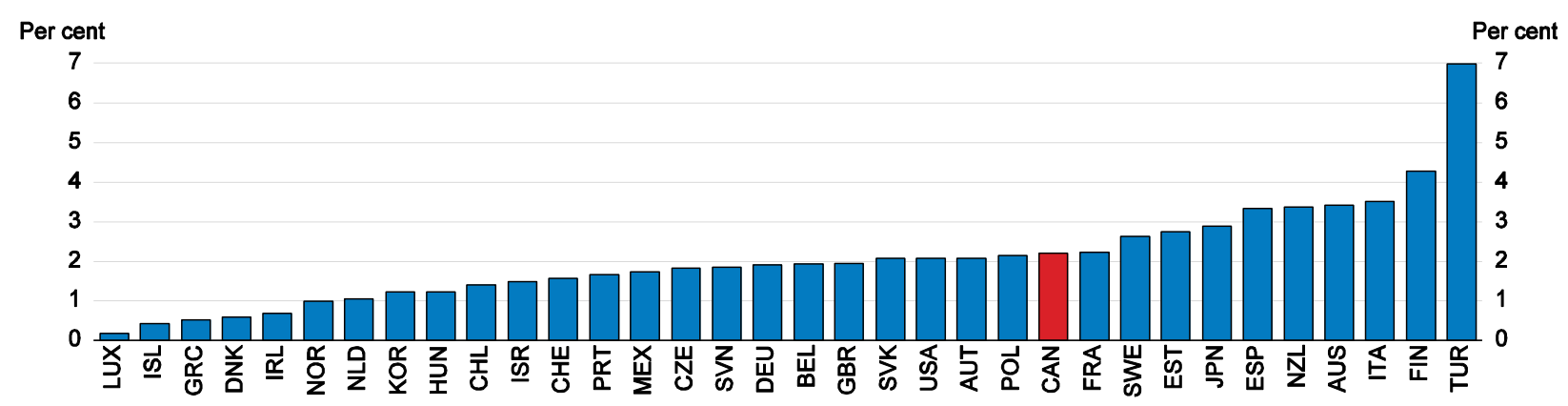

Source: OECD, Economic Outlook database; OECD-WTO, Trade in Value Added database.

Production scale also affects productivity. Measures that fragment markets and stifle competition limit the effective scale of production, lowering productivity and efficiency and increasing domestic prices. This includes barriers that restrict the movement of goods and services and reduce labour mobility across provincial borders.

Overall, this paper first discusses how competition in the network sectors of energy, telecommunications and broadcasting, and transportation may be strengthened through improving regulations and reducing interprovincial barriers. Second, the functioning of Canada's internal market is examined, including the Agreement on Internal Trade (AIT) and potential reforms that could improve its effectiveness. In addition, measures to enhance labour mobility and reduce sectoral barriers are discussed. Last, institutional reforms to improve the assessment of regulatory measures on competition are examined.

\section{Unleashing competition in network sectors}

\section{Energy}

Improving competition in the electricity sector, including through increased provincial market integration and the adoption of a more competitive market structure in generation, could raise efficiency, reduce potential overinvestment, increase the resilience of the system to potential electricity shortages, facilitate more affordable ways to achieve environmental objectives and permit increased integration of intermittent sources of electricity (such as solar and wind). The benefits of heightened competition on enduser prices will probably vary by province, as some are currently charging below-market rates by sharing the underlying resource rents with users. However, increased revenues in these provinces and improved returns to capital could be used to develop other infrastructure, fund programmes with higher returns, cut 
the most distortionary taxes or compensate those on low incomes and fight poverty, though they may also negatively affect competitiveness positions, given low US electricity prices. Natural gas markets, on the other hand, have comparatively low levels of regulation; past deregulation in this sector may provide a guide to better electricity market regulation.

\section{Electricity}

\section{Market structure}

Electricity markets are highly fragmented in Canada, owing to the provinces' central regulatory role. Federal regulation in this area is largely confined to the review and approval of international interconnections with the United States and oversight of nuclear safety and security. Integration between provincial electricity markets is generally limited, with no major east-to-west interconnections, other than between Ontario, Quebec and Newfoundland and Labrador. Most major interconnections run north to south into the United States, with more electricity being traded with the United States than between Canadian provinces.

Regulation in the Canadian electricity sector is heavy relative to most other OECD countries (Figure 3), reflecting a large share of public ownership and, to a lesser extent, limited vertical separation and high industry concentration in generation. According to the OECD's PMR indicators, the faster multifactor productivity gains available from liberalising current Canadian regulatory arrangements in the generation and distribution segments of this sector are moderate, at a little less than $0.1 \%$ per year in the medium term for the overall economy. Besides important differences among provinces in generation mix (Table 1, Panel A), there are also wide variations in market structures (Table 2) and ownership (Table 1, Panel B)), the impact of which on outcomes is highly controversial. In most provinces, electricity generation, transmission and distribution are controlled by a vertically integrated publicly owned monopoly, although in Nova Scotia and Prince Edward Island the monopoly is privately owned, and in Alberta there is a competitive structure. Some provinces have limited accounting separation between generation, transmission and distribution. However, electrical generation and marketing lack the same scale economies as distribution and transmission, implying that there is room for competition among generators. Competition could be enhanced if generation were fully separated from transmission and distribution, as long as generators are provided with non-discriminatory access to transmission lines at reasonable prices. This would require regulation and significant divestment by incumbent generators.

Figure 3. Sectoral regulation in the electricity sector

Index scale from 0 (least restrictive) to 6 (most restrictive), 2013

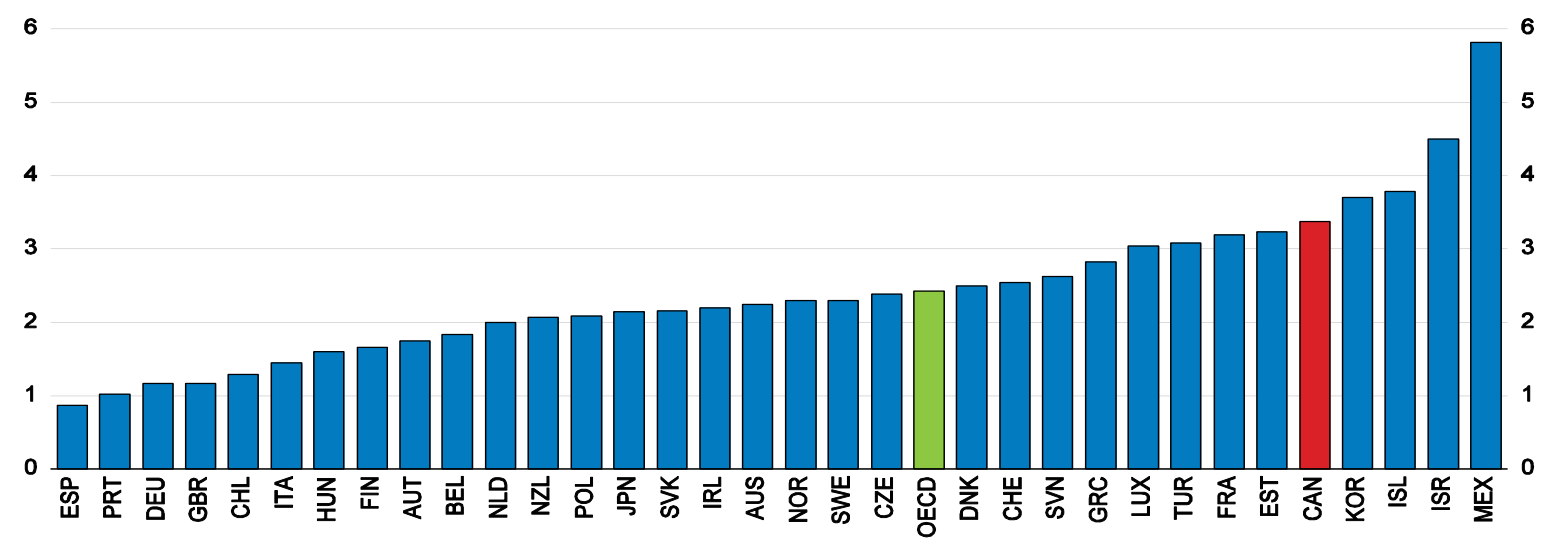

Source: OECD, Product Market Regulation database. 
ECO/WKP(2016)46

Table 1. Provincial electricity generation characteristics

Per cent, 2014 data

\begin{tabular}{|c|c|c|c|c|c|c|c|c|c|c|c|}
\hline & Canada $^{1}$ & $\begin{array}{c}\text { British } \\
\text { Columbia }\end{array}$ & Alberta & $\begin{array}{l}\text { Saskat- } \\
\text { chewan }\end{array}$ & Manitoba & Ontario & Quebec & $\begin{array}{c}\text { New } \\
\text { Bruns- } \\
\text { wick }\end{array}$ & $\begin{array}{l}\text { Nova } \\
\text { Scotia }\end{array}$ & $\begin{array}{l}\text { Prince } \\
\text { Edward } \\
\text { Island } \\
\end{array}$ & $\begin{array}{l}\text { Newfound- } \\
\text { land and } \\
\text { Labrador }\end{array}$ \\
\hline \multicolumn{12}{|c|}{ A. Generation by type } \\
\hline Coal & 10.4 & 0 & 69.3 & 46.6 & 0.1 & 0.0 & 0.0 & 15.9 & 53.9 & 0.0 & 0.0 \\
\hline Natural gas & 5.4 & 1.6 & 19.6 & 22.2 & 0.1 & 7.0 & 0.0 & 10.6 & 14.3 & 0.0 & 0.0 \\
\hline Nuclear & 17.5 & 0.0 & 0.0 & 0.0 & 0.0 & 63.0 & 0.0 & 33.4 & 0.0 & 0.0 & 0.0 \\
\hline Other fuels & 2.6 & 1.5 & 4.2 & 5.7 & 0.0 & 2.6 & 0.6 & 14.4 & 14.8 & 1.6 & 3.5 \\
\hline Hydraulic & 61.5 & 92.1 & 3.2 & 22.3 & 97.3 & 24.2 & 98.8 & 21.1 & 9.4 & 0.0 & 96.0 \\
\hline Wind & 2.0 & 0.3 & 3.6 & 3.2 & 2.4 & 2.8 & 0.6 & 4.6 & 7.4 & 98.3 & 0.5 \\
\hline $\begin{array}{l}\text { Other } \\
\text { (excl. fuels) }\end{array}$ & 0.5 & 4.5 & 0.0 & 0.0 & 0.0 & 0.2 & 0.0 & 0.0 & 0.1 & 0.0 & 0.0 \\
\hline $\begin{array}{l}\text { Share of } \\
\text { generation } \\
\text { from fuel }\end{array}$ & 36.0 & 3.1 & 93.2 & 74.5 & 0.3 & 72.7 & 0.6 & 74.3 & 83.1 & 1.6 & 3.5 \\
\hline \multicolumn{12}{|c|}{ B. Generation by ownership structure } \\
\hline Private & 25.7 & 7.0 & 82.9 & 12.1 & 4.5 & 41.2 & 6.6 & 20.1 & 100.0 & 79.3 & 4.1 \\
\hline Public & 74.3 & 93.0 & 17.1 & 87.9 & 95.9 & 58.8 & 93.4 & 79.9 & 0.0 & 20.7 & 95.9 \\
\hline
\end{tabular}

1. Including the Territories.

Source: Statistics Canada, Tables 127-006 and 127-009.

Only one province, Alberta, has competitive wholesale and retail electricity markets. Attempts to introduce more competition in other provinces, such as in Ontario and New Brunswick, have been partly or entirely reversed. Some provinces have undergone some pro-competitive restructuring to meet the US Federal Energy Regulatory Commission's (FERC) requirements to trade electricity with the United States, including establishing open-access transmission tariffs (OATTs) and utility unbundling driven by FERC's reciprocity requirements. OATTs allow third parties to transmit power to and from the United States over a province's transmission systems, but not transmission of power from one province to another.

Encouraging competition in generation and strengthening market pricing signals by establishing competitive wholesale markets could enhance efficiency (IEA, 2007), particularly for investment decisions. Investment efficiency could be further reinforced by nodal pricing (locational marginal cost pricing) for transmission, which could help identify the most efficient location and size for generation capacity (OECD, 2005). The impact of restructuring generation on retail prices is unclear; however, as past US reforms have shown that electricity prices become more sensitive to natural gas prices as natural gasfired plants tend to become the marginal producer (Borenstein and Bushnell, 2015). Therefore, the impact of restructuring on end-user prices would depend on the timing, particularly regarding natural gas price cycles, along with the composition of existing generation and the extent of regulatory provisions facing incumbents. 
ECO/WKP(2016)46

Table 2. Provincial electricity market characteristics

\begin{tabular}{|c|c|c|c|c|c|}
\hline & British Columbia & Alberta & Saskatchewan & Manitoba & Ontario \\
\hline General description & Regulated & Competitive & Regulated & Regulated & $\begin{array}{l}\text { Hybrid regulation and } \\
\text { competition model }\end{array}$ \\
\hline Main generation utility & BC Hydro & $\mathrm{N} / \mathrm{A}$ & SaskPower & Manitoba Hydro & Hydro One \\
\hline Provincially owned & Yes & No & Yes & Yes & Yes \\
\hline $\begin{array}{l}\text { Real time wholesale } \\
\text { market }\end{array}$ & No & Yes & No & No & Yes \\
\hline Transmission & BC Hydro & $\begin{array}{l}\text { ATCO Electric, } \\
\text { AltaLink } \\
\text { Management, } \\
\text { EPCOR Utilities, } \\
\text { ENMAX Power }\end{array}$ & SaskPower & Manitoba Hydro & $\begin{array}{l}\text { Hydro One, Great Lakes } \\
\text { Power, Canadian } \\
\text { Niagara Power, Five } \\
\text { Nations Energy and Cat } \\
\text { Lake Power Utility }\end{array}$ \\
\hline Distribution & $\begin{array}{c}\text { BC Hydro, } \\
\text { FortisBC, and } \\
\text { some municipal } \\
\text { utilities }\end{array}$ & $\begin{array}{l}\text { ENMAX, } \\
\text { EPCOR, ATCO, } \\
\text { FortisAlberta }\end{array}$ & SaskPower & Manitoba Hydro & More than 60 \\
\hline Retail prices & $\begin{array}{l}\text { Regulated cost-of- } \\
\text { service basis, } \\
\text { including a } \\
\text { stepped rate for } \\
\text { residential } \\
\text { consumers to } \\
\text { encourage } \\
\text { conservation }\end{array}$ & $\begin{array}{l}\text { Market based } \\
\text { with regulated } \\
\text { rate option } \\
\text { available for } \\
\text { residential, farm, } \\
\text { irrigation and } \\
\text { small commercial } \\
\text { users } \\
\text { (<250MWH/year) }\end{array}$ & $\begin{array}{l}\text { Regulated cost- } \\
\text { of-service basis }\end{array}$ & $\begin{array}{l}\text { Regulated cost- } \\
\text { of-service basis }\end{array}$ & $\begin{array}{l}\text { Competitive for } \\
\text { commercial and industrial } \\
\text { customers; more } \\
\text { regulated for residential } \\
\text { and small businesses } \\
\text { which choose between } \\
\text { an electricity retailer and } \\
\text { regulated default prices } \\
\text { (with time-of-use rates) }\end{array}$ \\
\hline & Quebec & New Brunswick & Nova Scotia & PEI & Newfoundland \\
\hline General description & Regulated & Regulated & Regulated & Regulated & Regulated \\
\hline Main generation utility & Hydro Québec & NB Power & NS Power & Maritime Electric & NL Hydro (Nalcor) \\
\hline Provincially owned & Yes & Yes & No & No & Yes \\
\hline $\begin{array}{l}\text { Real time wholesale } \\
\text { market }\end{array}$ & No & No & No & No & No \\
\hline Transmission & HQ TransÉnergie & $\begin{array}{l}\text { NB Power } \\
\text { Transmission }\end{array}$ & NS Power & Maritime Electric & $\begin{array}{c}\text { NL Hydro and } \\
\text { Newfoundland Power }\end{array}$ \\
\hline Distribution & $\begin{array}{l}\text { HQ Distribution + } \\
9 \text { municipal } \\
\text { distribution } \\
\text { companies }\end{array}$ & $\begin{array}{l}\text { NB Power } \\
\text { Distribution and } \\
\text { Customer } \\
\text { Service }\end{array}$ & $\begin{array}{l}\text { NS Power + six } \\
\text { municipal } \\
\text { utilities }\end{array}$ & Maritime Electric & $\begin{array}{l}\text { NL Hydro and } \\
\text { Newfoundland Power }\end{array}$ \\
\hline Retail prices & $\begin{array}{l}\text { Regulated cost-of- } \\
\text { service basis }\end{array}$ & $\begin{array}{l}\text { Regulated cost- } \\
\text { of-service basis }\end{array}$ & $\begin{array}{l}\text { Regulated cost- } \\
\text { of-service basis }\end{array}$ & $\begin{array}{l}\text { Regulated cost- } \\
\text { of-service basis }\end{array}$ & $\begin{array}{c}\text { Regulated cost-of-service } \\
\text { basis }\end{array}$ \\
\hline
\end{tabular}

Source: London Economics International (2014), Power Prices in Context: Comparing Alberta Delivered Electricity Prices to Other Canadian Provinces on a Level Playing Field, June; P-O. Pineau (2013), "Fragmented Markets: Canadian Electricity Sectors' Underperformance", in Evolution of Global Electricity Markets, Elsevier, London; Statistics Canada.

Such liberalisation could take the form of "energy-only markets", where wholesale prices are based solely on marginal cost, as in Alberta, or the incorporation of additional capacity charges (through a capacity market), similar to PJM Interconnection in the United States (PJM is a regional transmission organisation, which coordinates the movement of wholesale electricity in most North-Eastern states) and as is currently being considered by Ontario's Independent Electricity System Operator. In such a system, generators would be paid for making capacity available to produce electricity on top of payments for actual production at a given price during a given hour. Such capacity markets have been motivated by concerns 
that energy-only markets may result in low investment levels and small reserve margins, which may hinder system reliability. On the other hand, capacity charges may also drive up energy costs for consumers relative to energy-only markets. Measures to introduce more competition in generation should be combined with efforts to increase integration between provincial and international markets (discussed below), which could make the system more resilient to power shortages. A public backlash from shortages and high price volatility in Ontario in the early 2000s, for instance, significantly reduced support for electricity reforms. Provinces should review the current structure of the electricity sector and devise a strategy to increase wholesale competition, including measures to make the system more resilient to supply shortages.

Where generation has been deregulated and competitive wholesale markets established, ensuring protection against anti-competitive practices and, more broadly, confidence and trust that regulatory decisions are objective, impartial and consistent through an independent regulatory body remains essential (OECD, 2014c; OECD, 2015a). Even in competitive and non-concentrated generation markets, the existence of inelastic electricity demand and supply during peak periods gives rise to market power, as some electricity producers may choose to restrict capacity to drive up prices, as recently occurred in Alberta (Henton, 2015). Many provinces have well established regulatory bodies, in part to ensure nondiscriminatory access to transmission and distribution facilities. Where deregulation has occurred and competitive generation established, such bodies will also need to continue to monitor the provision of generation capacity to guard against anti-competitive practices.

Competition in the distribution segment (i.e. at the retail level) would enable consumers to pick their electricity suppliers, which could incentivise the development of offers tailored to consumers' needs (e.g. lower off-peak electricity prices), though it could also lead to the development of opaque contracts and thus lower consumer welfare, unless offering a common basic contract is required. Retail competition is currently limited in Canada, with retail electricity prices generally regulated on a cost-of-service basis (average cost pricing). However, Alberta, and, to a lesser extent, Ontario have liberalised markets. Nevertheless, even in these markets the availability of regulated retail rates which may deter entry and high search costs may be limiting effective competition. In Alberta, for instance, despite the freedom to choose a retail provider, the majority of households, farms and small commercial consumers use the default regulated rate option (which is available for those using less than $250 \mathrm{MWH}$ per year) from their local distributor (Kemp, 2014). More intensive educational efforts, increased transparency of price comparisons, a phasing out of the regulated rate option (which has been extended until 2018) and the establishment of a Provider of Last Resort as in Texas, as recommended by the Retail Market Review Committee in Alberta in 2012, could enhance retail competition.

Increased retail competition would probably benefit large more than small consumers, as the potential for cost savings would rise with increased usage. Past North American deregulation has shown that commercial and industrial users tend to make up a greater share of new entrants' clientele, while a relatively small share is accounted for by residential customers, who tend to choose regulated fixed prices (Brennan, 2008). In Alberta, for instance, 96\% of large, and $71 \%$ of small, commercial and industrial consumers received competitive electric service (i.e. not on the regulated rate option) from non-incumbent providers in 2014, relative to $43 \%$ for residential users (DEFG, 2015). This said, households would benefit indirectly through lower costs for goods and services provided by industrial and commercial firms who, in a competitive marketplace, would pass on their electricity cost savings.

\section{Electricity prices}

Electricity prices for households and businesses are low in Canada compared with other OECD countries (Figure 4, Panel A). However, they vary considerably throughout the country primarily reflecting resource endowments, with hydro-abundant provinces exhibiting the lowest rates; however, provincial 
policies also play a role (Panels B and C). In hydro-dominant provinces implicit provincial guarantees reduce borrowing costs, while suppressed equity returns at provincially owned utilities, export revenues and heritage contracts may also hold prices down. For instance, Manitoba Hydro is prohibited from charging a rate of return on its cost of service (only operating and capital costs can be charged), and it rarely pays dividends (Pineau, 2013), cutting user prices. Yet, there is no sign of underinvestment because sub-market returns are not sanctioned by the provincial owner (as it would be in a private company), since it is deliberate.

Figure 4. Electricity prices

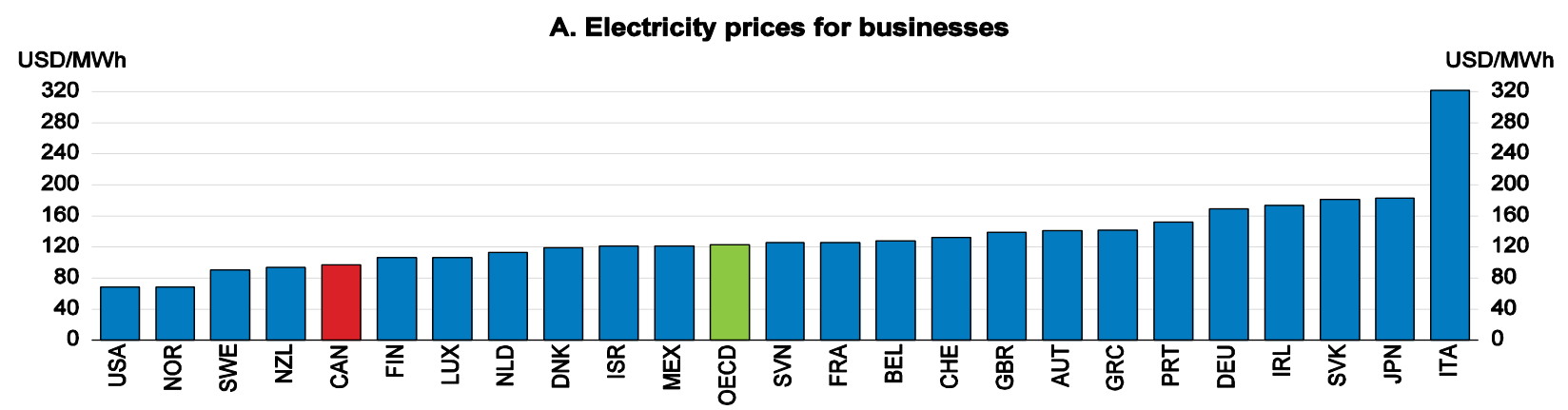

B. Electriclty prices for households

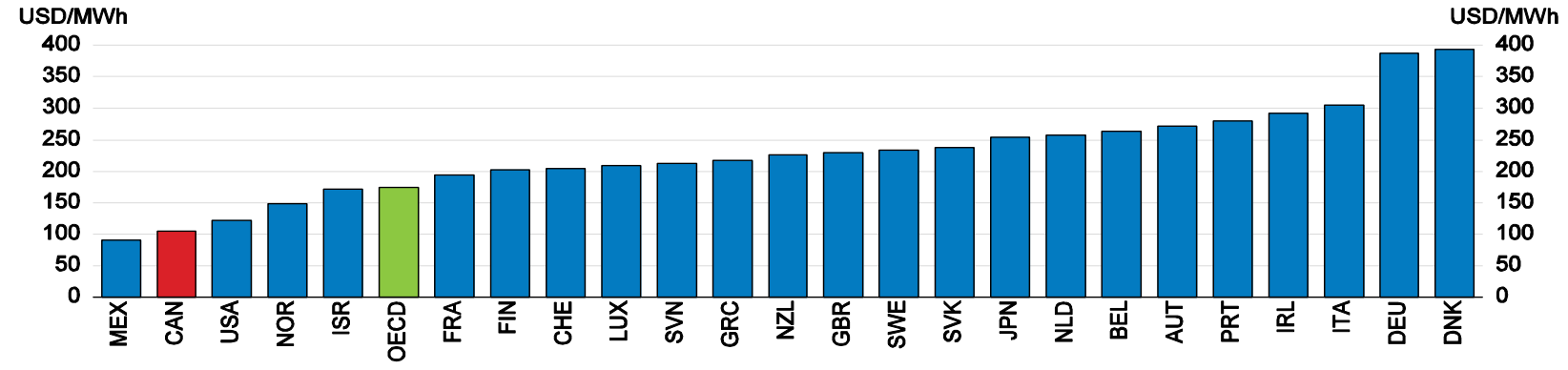

C. Provincial electricity prices adjusting for various distortions

$\square 013$ rates
Residential customers

CAD cents/kWh

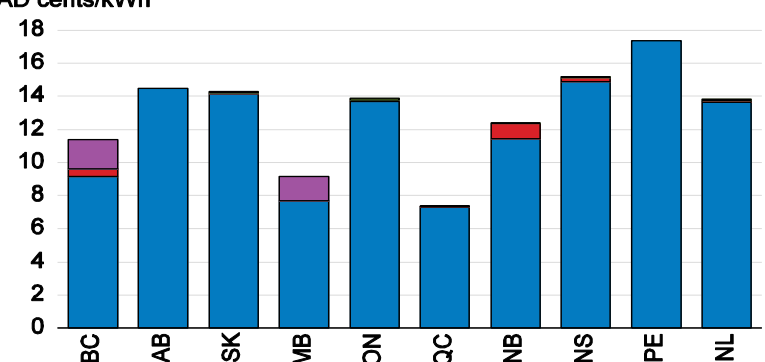

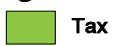

Tax

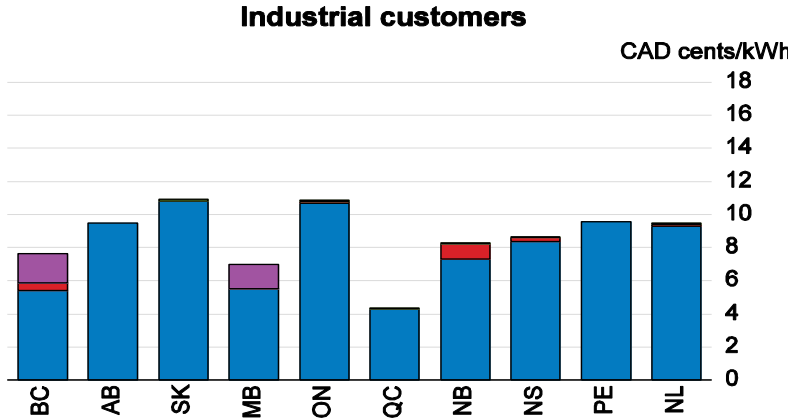

Source: IEA, Energy Prices and Taxes database; A.J. Goulding and M. Atanasov (2014), Power Prices in Context: Comparing Alberta Delivered Electricity Prices to other Canadian Provinces on a Level Playing Field, London Economics International.

How to read this figure: Panel C presents an estimate of what provincial prices would have been in 2013 if various differences between provincial energy markets were removed. The blue bars show actual electricity rates, while the additional variables show the marginal contribution of removing these effects or making policies more similar to Alberta for comparison purposes.

Reduced risk exposure and less informative price signals that result from lower borrowing costs, taxes and implicit subsidies for publically owned monopolies may result in a misallocation of resources away from other public programmes and infrastructure where returns may be greater. In addition, taxpayers bear the risk of over-investment in generation capacity, which may be reinforced by fixed-price contracts, whereas in a private firm such risks would be borne by shareholders. 
Some efforts have been made to incorporate price incentives to reduce peak-period consumption in some provinces, thereby attempting to limit the amount of investment needed to meet peak demand. These demand-side policies, such as time-varying prices, could also help to increase the price elasticity of electricity demand, by encouraging consumers to shift consumption to periods of lower demand rather than paying a time-averaged price, reducing the size of price spikes and thereby reducing generators' market power (OECD, 2005). Ontario has invested in smart meters to allow time-of-day pricing for households, farms and small businesses that use less than $250 \mathrm{MWH}$ per year and has implemented the Industrial Conservation Initiative (High-5 programme) to encourage large industrial consumers to reduce peak-period consumption. However, this programme results in distortions from cross-subsidisation of electricity costs (Box 1). To level the playing field, the Ontario government should move to make the regulated portion of electricity prices ("Global Adjustment") a function of energy consumption for all consumers, as is the case for small industrials, commercial firms and households (Class B; see Box 1), and continue to expand the use of demand-management tools more broadly. Additionally, weighting energy consumption in peak periods more heavily than in off-peak periods when distributing the regulated portion between customers would be equitable, as those that consume electricity disproportionately in peak periods contribute more to the need to invest in costly peaking capacity. 


\section{Box 1. Electricity prices in Ontario and the Global Adjustment}

Electricity prices in Ontario have been moving further away from competitive market signals, reflecting price guarantees to generators through contracts with the Ontario Energy Board (OEB) and regulated rates for government-owned nuclear and hydro facilities. Ninety-one per cent of Ontario's energy production is under contract to the OEB (contracts can be as long as 20 years) or have fixed, regulated prices (Goulding, 2013). The wholesale spot price (Hourly Ontario Electricity Price) has tended to fall since the mid-2000s, and differences between the higher guaranteed prices for generators and the low wholesale market-clearing rates have been charged to consumers through the so-called Global Adjustment (GA). The GA now makes up the majority of average retail electricity prices for consumers (Figure 5).

\section{Figure 5. Electricity prices in Ontario}
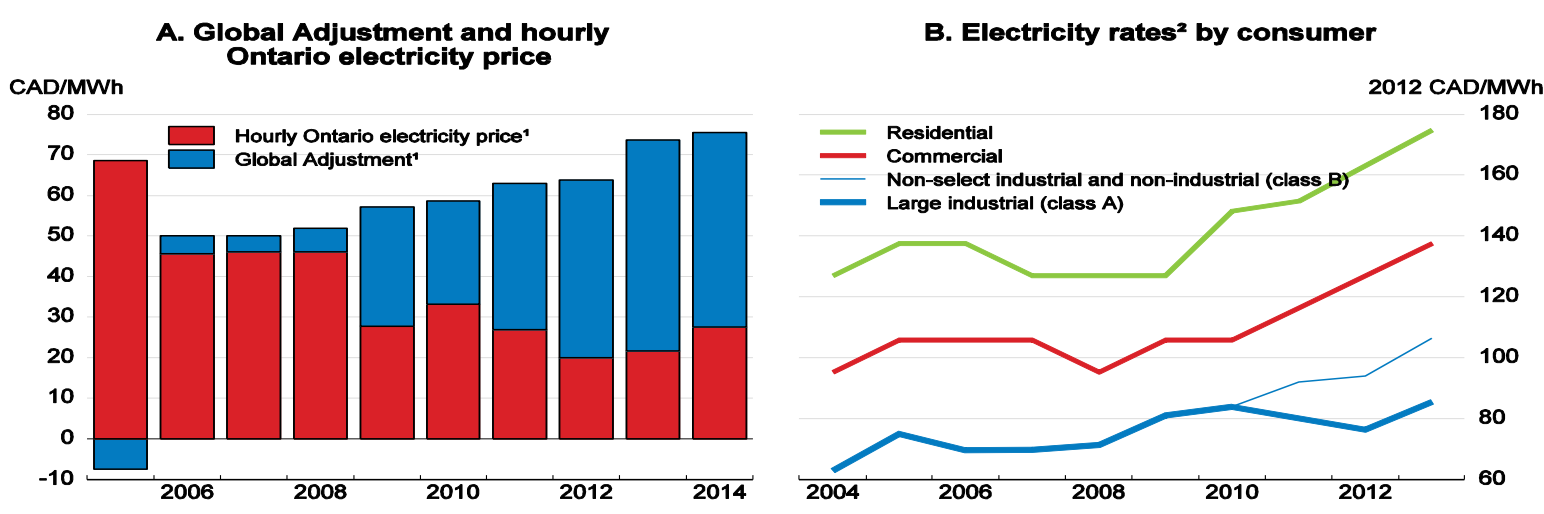

1. Deflated by the Ontario consumer price index.

2. Inflation-adjusted at 2012 prices, Ontario Clean Energy Benefit (OCEB) power rates.

Source: Independent Electricity System Operator (IESO); R. McKitrick and T. Adams (2014), What Goes Up - Ontario's Soaring Electricity Prices and How to Get Them Down, Fraser Institute.

McKitrick and Adams (2014) show this increase in the GA may reflect the move towards renewable sources of electricity. In particular, Ontario's Feed-in-Tariff programme provides implicit subsidies to renewable energy producers, probably increasing the GA, and these costs are projected to rise further in the future (Goulding, 2013; OEB, 2015). Transitioning towards market-based prices or potentially establishing a capacity market could allow the system to be more dynamic, particularly in the case of technological innovation, provide a more economical energy mix and incorporate a market-based response to the government's environmental goals, given Ontario's imminent establishment of a cap-and-trade scheme for greenhouse gases.

Potential distortions have also been introduced based on how the GA is distributed among users, particularly for smaller industrials and other businesses. Since the Industrial Conservation Initiative (High-5 programme) began in 2011, customers have been classified into two categories based on peak electricity consumption and industry to calculate their GA charge. GA costs for large industrials (Class A, which since 2014 has been those using more than $3 \mathrm{MW}$ ) are based on the share of electricity consumption during the five peak load hours by all Class A customers. This portion is then split between individual Class A consumers based on their share of usage during these peak demand periods in the year. The remaining portion of the GA is allocated to other customers, including small industrials, commercial businesses and households (Class B, $<3 \mathrm{MW}$ ) based on their share of usage as a proportion of total electricity consumption during the billing period.

The rationale for these differing rates was to encourage large industrial customers to reduce peak demand, thereby lowering required capacity. Even though there is some evidence that large industrials are able to anticipate peak periods (Sen, 2015), they may do so rather imprecisely, as the top five peak periods during the year are not known in advance. Additionally, this policy has resulted in cross-subsidisation of large industrials' electricity costs by small industrials and other consumers (McKitrick and Adams, 2014; Panel B). It is estimated that the High-5 programme will be responsible for up to one-quarter of the expected increase in electricity costs for households planned for 2016 (Sen, 2015). 
ECO/WKP(2016)46

\section{Market integration}

Further developing interconnections between provinces and with the United States could improve competition, enhance system reliability -- thereby facilitating electricity market deregulation -- and smooth the integration of intermittent renewable generation. The resulting increase in the geographic scope of markets could also help to reduce the market power of generators (OECD, 2005) and price volatility, which eroded public support for a more competitive market structure in the wake of Ontario's 2002 reforms. Improved integration with other provinces and the United States could help to limit such volatility as the electricity base would be larger, rendering the system more resilient to supply shortages or sudden surges in demand.

Enhanced interconnectivity could also improve system efficiency resulting from the varying electricity mixes across the country. Hydroelectric systems depend heavily on water levels, making them sensitive to variations in rainfall, while fuel-based generation systems (natural gas, coal or uranium) depend on costly fuel inputs. With low interprovincial integration, electricity generation in both these cases may exceed provincial requirements in order to ensure adequate supply. This excess may be reduced if more alternatives were available through interconnections, improving the efficiency of infrastructure use. Further integration could also make greater use of hydroelectric storage capability, which would allow fuel-based (including nuclear) generation to be imported off peak when it is in surplus (and reservoirs are rebuilt) and save hydroelectric energy for peak times.

Strengthening electricity integration could also facilitate a move towards more renewable yet intermittent resources, such as wind and solar electricity. Averaging the variations in generation over larger geographical areas, through increased interconnectivity, could increase the viability of such sources. Efforts to increase integration have been the strongest in Atlantic Canada, where isolation and concentrations of intermittent supply (such as wind power in Prince Edward Island) have reinforced their payoff. The federal government has provided support for the Atlantic Energy Gateway (AEG) initiative, a federal-provincial-utilities collaboration aimed at enhancing regional cooperation. AEG modelling and research studies determined that improved regional collaboration (including interconnections and infrastructure planning) could yield significant opportunities for operating cost efficiencies through joint infrastructure planning and regional balancing of supply and demand, while achieving greater diversity in clean and renewable energy supplies, enhanced rate stability and reduced greenhouse gas emissions. At the same time, the economic rationale for constructing an east-west electricity grid in Canada may not be clear. Traditionally, electricity has flowed north-south because distances, and the costs of transporting electricity, between Canadian supply and U.S. demand can be shorter than the east-west gap between one province and another. Because of the costs of transporting electricity over long unpopulated areas, the economics of a national grid may not necessarily be good. However, improving the trade opportunities between adjacent provinces, where incremental opportunities for mutual gain exist, may be beneficial.

The federal government could continue to support increased integration of provincial electricity markets by expanding initiatives like the Atlantic Energy Gateway to other regions and promote the development of further interconnections, including with the United States. Provinces should work together to reduce barriers to trade in electricity and implement new interconnections and more competitive market structures in their regions. This could include establishing a chapter on energy (including electricity) in the Agreement on Internal Trade (AIT), the main agreement to reduce interprovincial barriers to trade through the Council of the Federation (see below). Other avenues for collaboration include the annual Energy and Mines Ministers Conference and its Federal-Provincial-Territorial Electricity Working Group. Moreover, promoting collaboration between the provincial regulators, as in the Council of European Energy Regulators, could allow exchanges of best practices and encourage the development of a single domestic energy market. These efforts will create a more conducive environment for investment and cooperation; however, the federal government has in some cases stepped in to subsidise investments, which may 
weaken market discipline. In particular, the federal government has also supported some major generation and transmission projects through debt guarantees, thereby reducing borrowing costs. For instance, in December 2013 it provided a combined guarantee for CAD 5 billion in debt for the Muskrat Falls generation project, Labrador Transmission Assets and Labrador-Island Transmission Link, and, in March 2014, for CAD 1.36 billion for the Maritime Link. These guarantees are estimated to lower interest costs by CAD 1 billion and CAD 325 million in interest, respectively, over the projects' lifetimes (Government of Newfoundland and Labrador, 2013; Emera, 2014).

In response to electricity costs, supply considerations and changing energy mixes, some provinces are exploring options to increase provincial interconnections or use existing ones more regularly. For example, Quebec and Ontario signed a memorandum of understanding in late 2014 to establish a $500 \mathrm{MW}$ capacity exchange arrangement (using existing interconnections) that supports the reliability of each other's electricity systems by taking advantage of their complementary seasonal peaks in electricity resources and needs. Several additional cross-border interconnections are also planned or under construction between Canada and the United States and in Atlantic Canada.

Integration could aid in reducing electricity prices in fuel-dominant provinces. However, in provinces with substantial hydro-electricity (British Columbia, Quebec, Newfoundland and Manitoba) power is generally sold below opportunity cost (based on potential export revenues) (Figure 4; Pineau, 2008). This has provided an implicit subsidy for businesses and households, which tends to be larger for higher-income households as they tend to consume more electricity (Figure 6, Panel A; Pineau 2008). Overall, belowmarket rates have boosted energy consumption (Panel B) and resulted in low rates of return on investments. Part of the increase in per capita consumption reflects a switch to electricity for heating in low-cost provinces. Increased integration would probably raise electricity prices in these provinces and could be met with resistance, particularly from households and energy-intensive industries (e.g. mining). In a more competitive and integrated market, higher electricity revenues could be used to cut the most distortionary taxes, lower corporate taxes more broadly, invest in infrastructure or social programmes where the returns may be greater, or compensate those on low incomes and fight poverty. However, higher prices may lead some energy-intensive industries to become less competitive, given that electricity prices are lower in some US states. As external demand for power from hydro-producing provinces may rise, authorities need to ensure that future projects internalise environmental consequences and that Canadian Indigenous Peoples communities are engaged in the planning process to minimise damage to traditional hunting and fishing grounds. 
Figure 6. Residential electricity sales

\section{A. Average household energy use in Canada by income quintile, 2011 \\ Gigajoules per household}

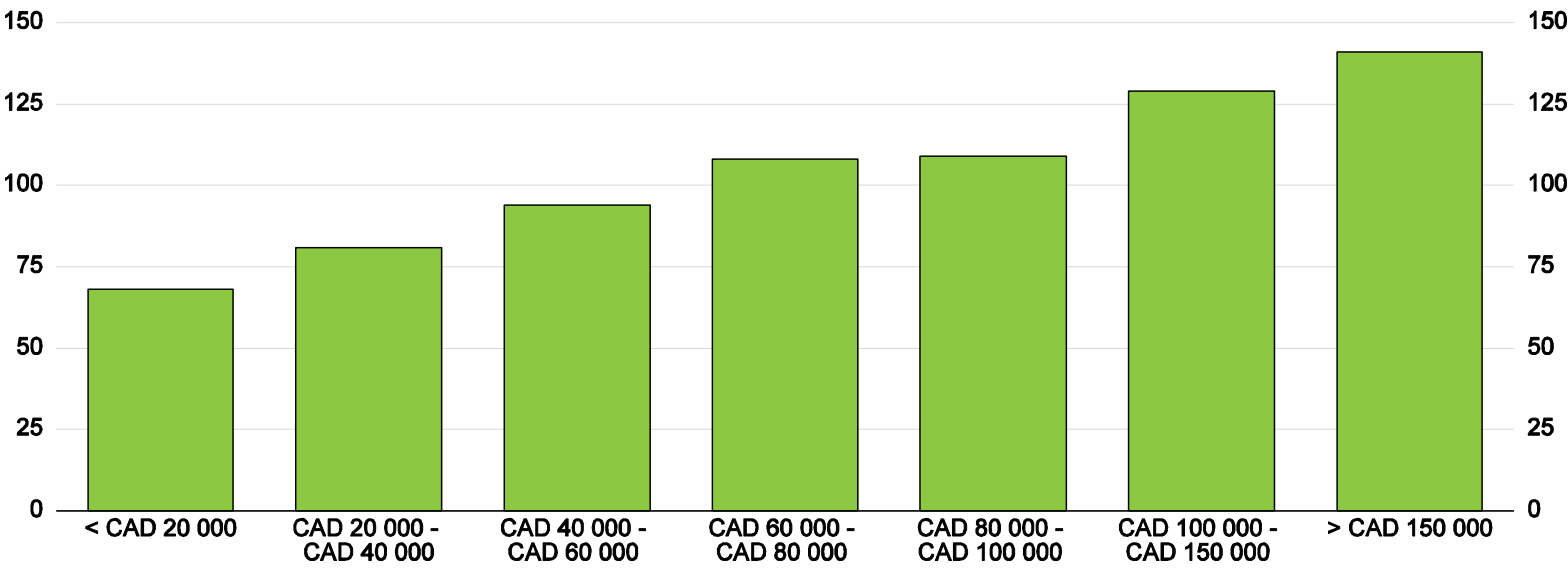

B. Residential electricity consumption and prices by province, ${ }^{1} 2013$ Annual residential consumption per capita (MWh)

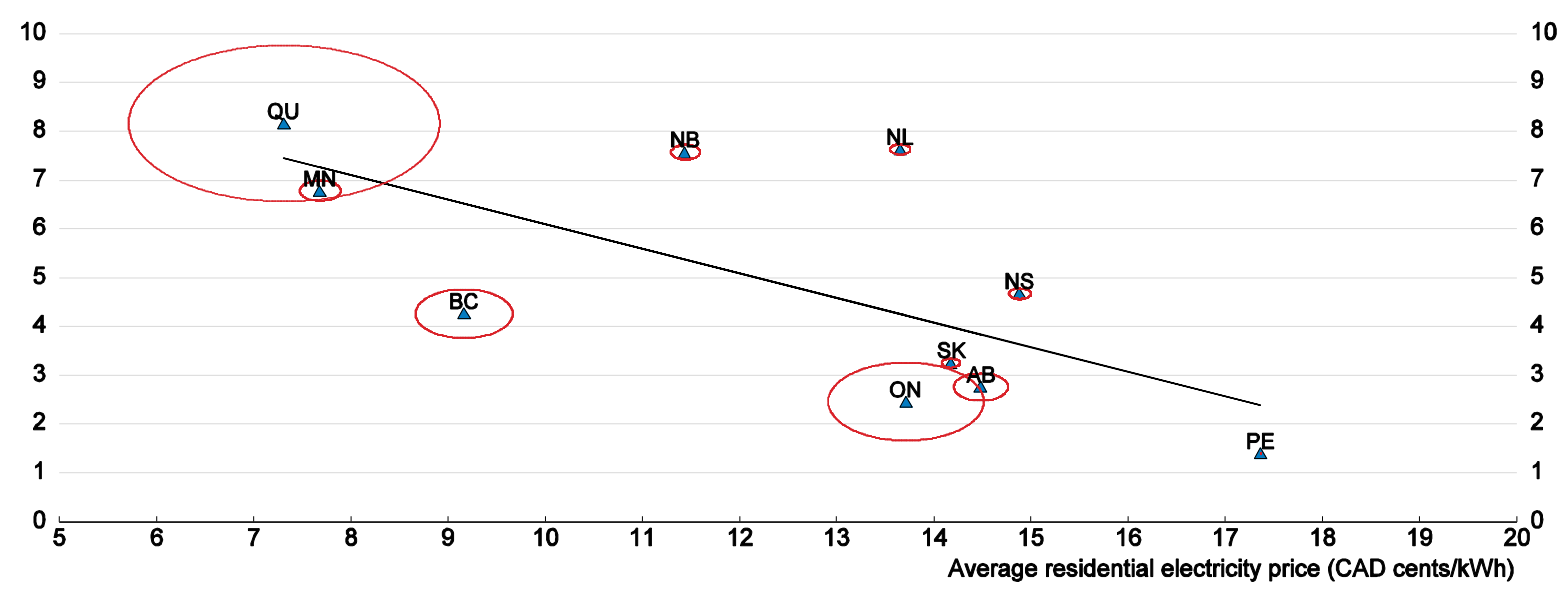

1. The size of the bubbles represents the total volume of residential electricity sales in the province.

Source: Statistics Canada, Tables 127-0008 and 051-0001, http://www.statcan.gc.ca/pub/11-526-s/2013002/t010-eng.htm; A.J. Goulding and M. Atanasov (2014), Power Prices in Context: Comparing Alberta Delivered Electricity Prices to other Canadian Provinces on a Level Playing Field, London Economics International; and OECD calculations.

\section{Natural gas}

North American natural gas markets are heavily inter-connected. Provinces have legal jurisdiction over most upstream and downstream activities, while the National Energy Board (NEB) is responsible for the approval and regulation of natural gas pipelines in Canada that cross provincial or international borders. The federal government is also involved in environmental assessments and permitting of major developments. Regulation in the natural gas sector is light by OECD standards (Figure 7). Natural gas prices are comparatively low in Canada (Figure 8), reflecting ample domestic supply and the availability of cheap imports from the United States, particularly in Eastern Canada. But variation across provinces and even within the larger provinces is substantial.

The Canadian natural gas market was liberalised in the 1980s, led by price deregulation in 1985 . The upstream industry is highly competitive, with close to 700 operating producers (IEA, 2016). Wholesale 
prices are determined on the open market, with purchases primarily on a spot or short-term basis. Transmission and distribution assets are largely privately owned, and tolls are regulated (by the NEB

Figure 7. Regulations in the natural gas sector are low Index scale from 0 (least restrictive) to 6 (most restrictive), 2013

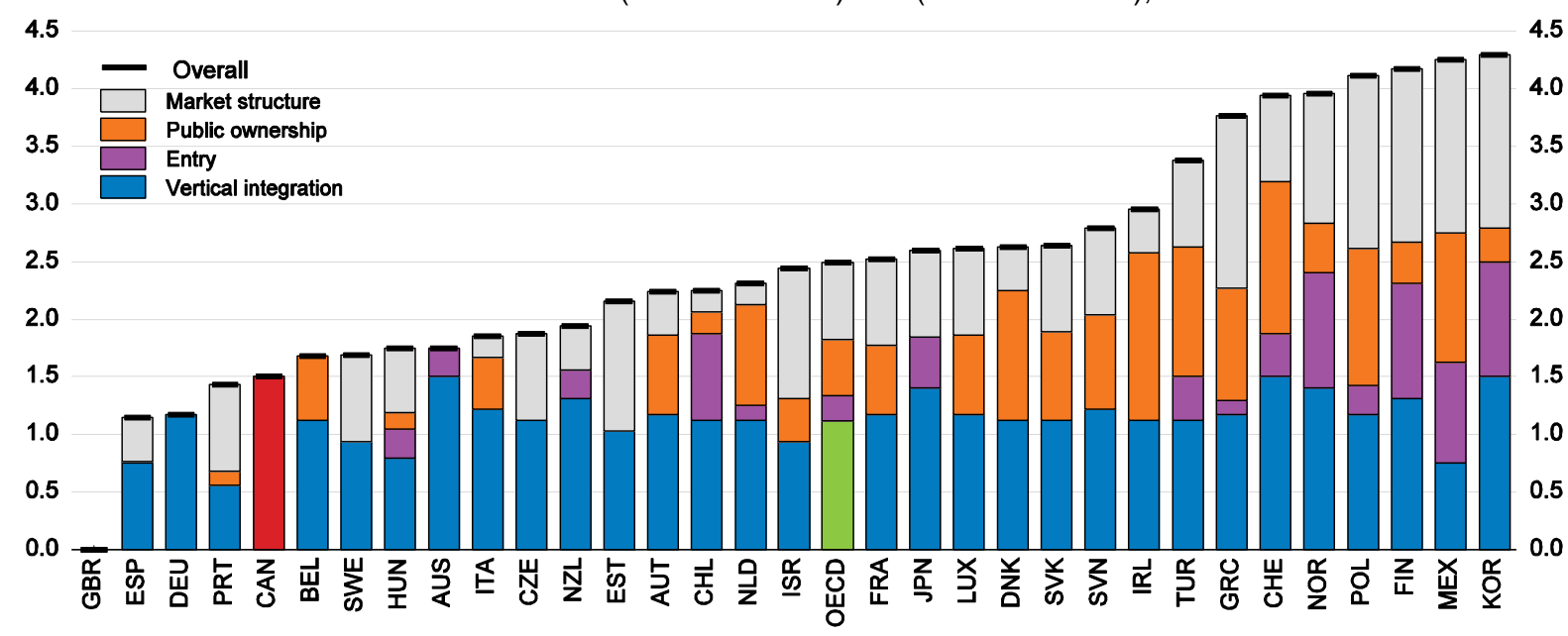

Source: OECD, Product Market Regulation database.

Figure 8. Natural gas prices ${ }^{1}$ are low in Canada, 2014

A. Prices for businesses

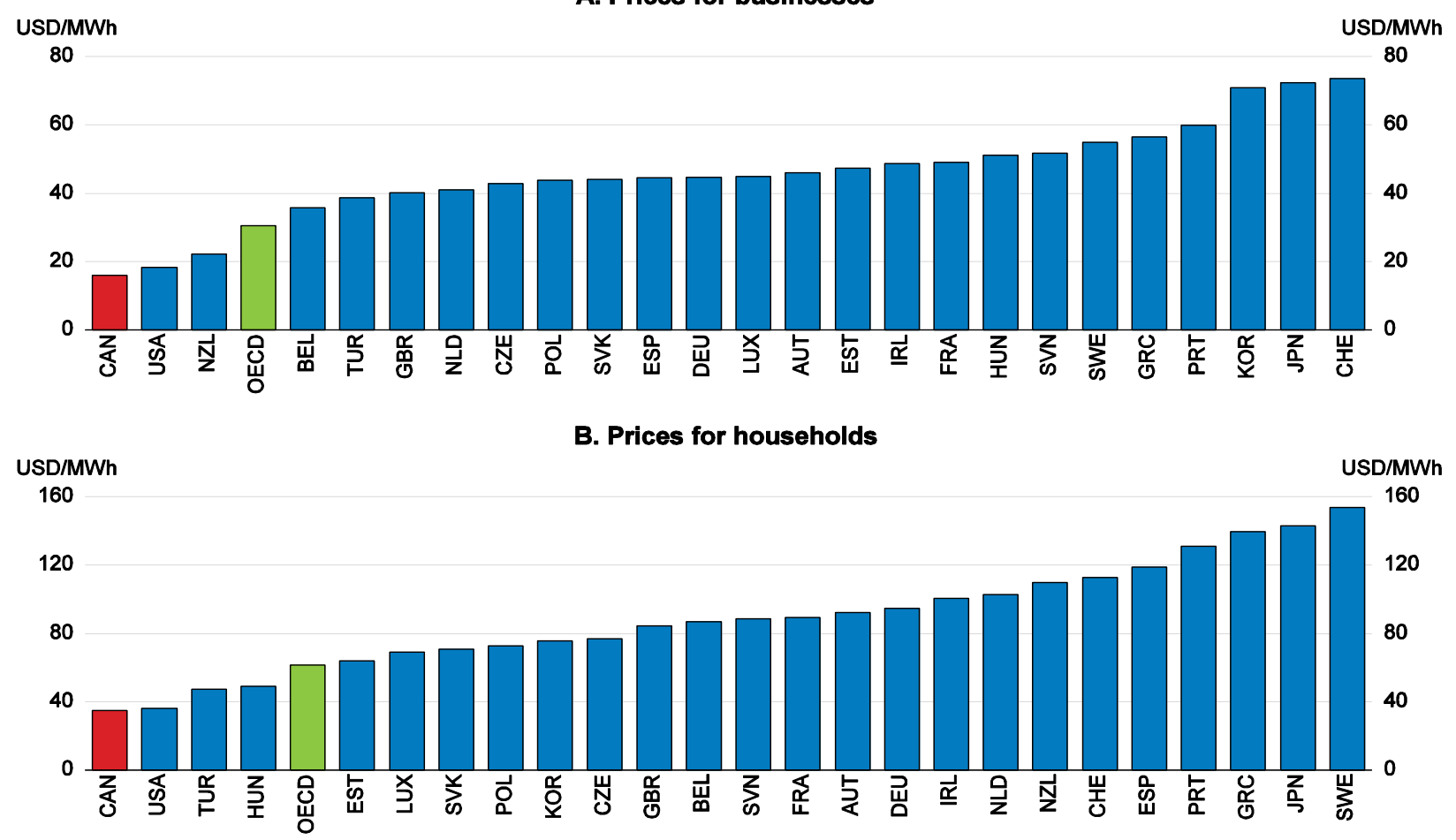

1. Including taxes.

Source: IEA, Energy Prices and Taxes database.

for transmission and provincial utility boards for distribution). In particular, gas transmission pipelines are required to provide non-discriminatory open access to shippers, and tolls are regulated under the NEB Act to cover pipeline fixed costs and variable operating costs. Distribution rates and returns on equity are provincially regulated. Retail prices are regulated by the provinces on a cost-plus basis, which includes the 
commodity, pipeline transmission and distribution costs, a mark-up and taxes. Provincial regulators also ensure that gas purchases are done on a prudent basis. As highlighted in the 2004 Survey (OECD, 2004), lessons from the deregulation of the natural gas sector could be informative for electricity market reforms, particularly in the development of wholesale competition and market access.

All Canadian natural gas exports are currently destined for the United States, and following rising US unconventional gas production, exports, and hence production, have weakened. After peaking in 2007, exports have declined by nearly a third, with volumes in 2014 comparable to those in the mid-1990s. A key challenge for the sector will be to develop infrastructure to diversify export markets, including building liquefied natural gas (LNG) terminals and associated pipelines. Currently, fully 25 LNG liquefaction projects are awaiting approval and final investment decisions, with three projects moving ahead in 2015 (IEA, 2016). The first LNG exports could start in 2019, but opposition on environmental grounds is heavy, not only for the impact of the associated pipelines but because of the GHGs that would be produced by exploiting the gas. In its 2015 budget, the federal government took initiatives to encourage private infrastructure investment, including extending natural gas export licences (issued by the NEB) from 25 to 40 years to increase regulatory certainty, and implementing an accelerated capital cost allowance for liquefaction facilities. On the domestic front, major projects are underway to increase the share of natural gas in electricity production, particularly in provinces with a large share of coal-fired generation, which should support overall demand and reduce carbon emissions.

\section{Recommendations to improve competition in the electricity sector}

- Work with the provinces to increase provincial electricity market integration, including developing further east-west interconnections and planning infrastructure regionally, when there is an economic case to do so. Similarly, work with the US government to further increase international trade in electricity.

- Include an energy chapter (including electricity) in the revised Agreement on Internal Trade.

- Extend initiatives to other regions like the Atlantic Energy Gateway that bring together governments and producers.

- Work with the provinces to liberalise the generation and distribution segments. Promote the establishment or strengthening of wholesale and retail competition by, for example, establishing real time wholesale markets as in Alberta and phasing out regulated rate offers in established competitive markets for residential and small electricity users.

- Increase educational efforts in markets with retail competition to encourage consumer switching.

\section{Telecommunications and broadcasting}

Telecommunication services and broadcasting fall under federal government responsibility. Regulations in the telecommunication sector are guided by the Telecommunications Act and in broadcasting by the Broadcasting Act. The Canadian Radio-Television and Telecommunications Commission (CRTC) is an independent regulator responsible for interpreting these Acts, though their findings are subject to federal government review and approval. As in other OECD countries, convergence between telecommunication services and broadcasting is increasingly blurring the lines between these two sectors. Although much of the supply of telecommunication services in Canada has been liberalised, the sector remains concentrated, with the five largest incumbent providers accounting for more than $84 \%$ of total telecommunication revenues in 2014 (CRTC, 2015). Approximately 94\% of these revenues were from forborne services (i.e. from services that the CRTC has determined are sufficiently competitive that tariff filings are no longer required) (CRTC, 2015). The sector is also characterised by a high level of vertical integration, with large telecommunication players also present in broadcasting. 
Canadian telecommunication services are of high quality: for broadband this is borne out by indicators such as above-average download speeds (Figure 9). However, telecommunication services

Figure 9. Telecommunications quality indicators
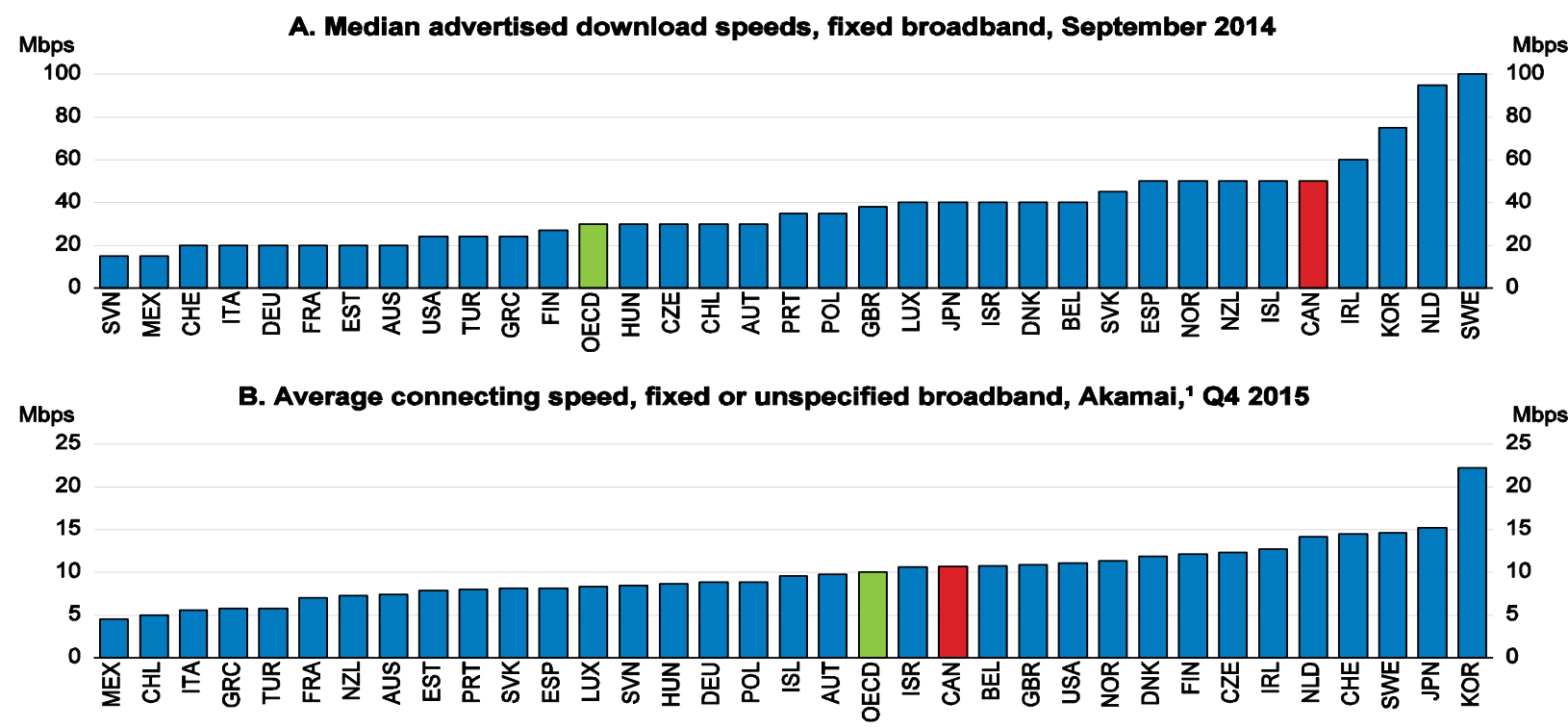

C. Moblle broadband advertlsed speed ranges, September 2014

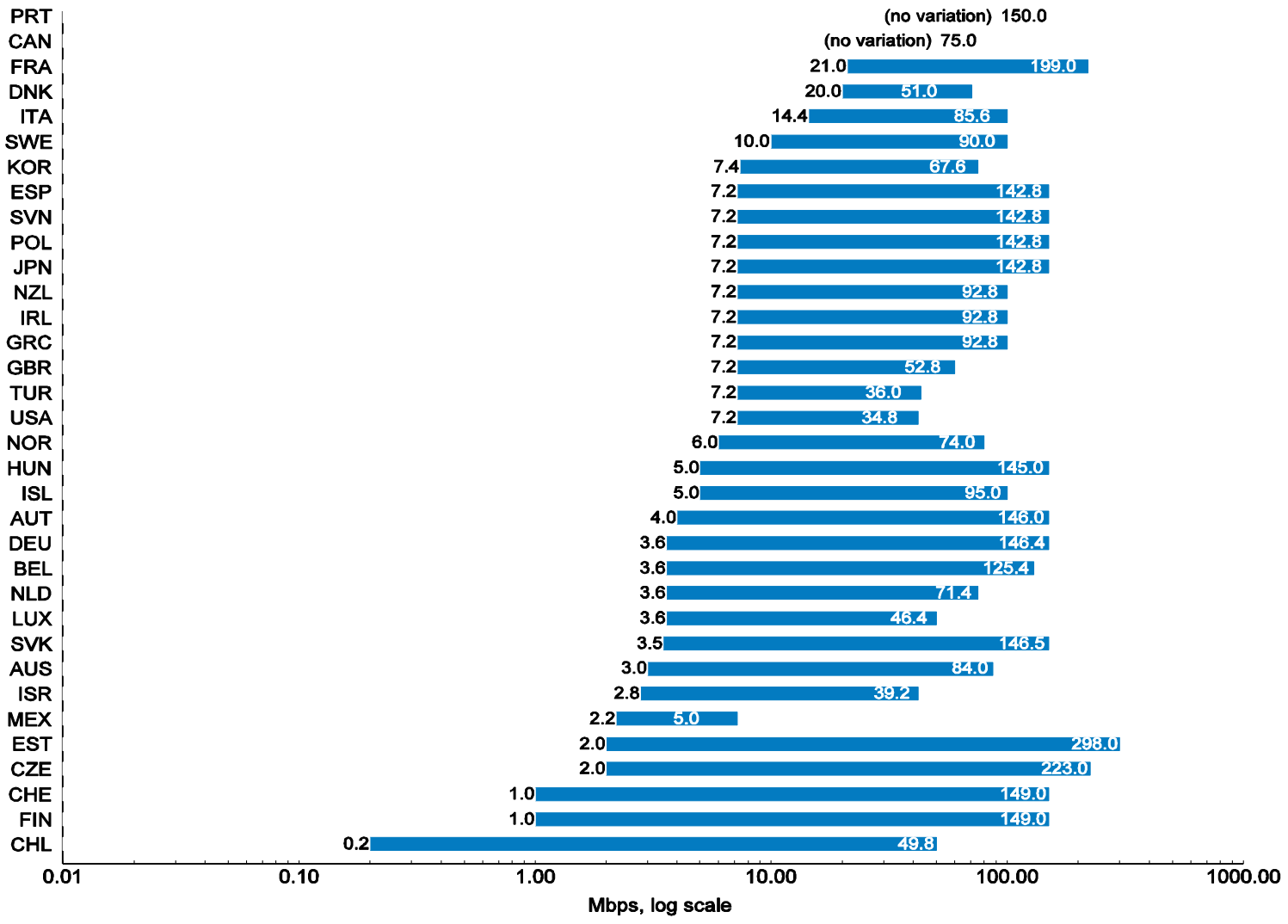

1. This measure excludes mobile broadband users from its average connection speed metrics.

Source: OECD (2015), OECD Digital Economy Outlook 2015, with updates. 
are also relatively expensive. Mobile subscription numbers are fairly low, while fixed broadband adoption rates are above the OECD average. Prices for mobile baskets (mobile calls and broadband), fixed broadband and bundles that include television, fixed broadband and fixed calls (and more expansive bundles that also include mobile services) are comparatively high in Canada (Figure 10), especially for fixed broadband. This is consistent with the latest annual CRTC price-comparison report prepared by Wall Communications Inc. (2015), which conducts price comparisons for Canada relative to the G7 countries plus Australia. This report found that Canadian prices for wireline, mobile wireless, high-speed broadband, mobile Internet and bundled services are at the high end. Based on these findings, it is possible to infer that these higher prices may have reduced demand for mobile and wireless broadband subscriptions, although fixed broadband subscriptions stand above OECD averages (Figure 11). The fewer subscriptions for mobile and wireless may also reflect the large geographical distances, given thinner rural coverage.

Figure 10. Telecommunications prices

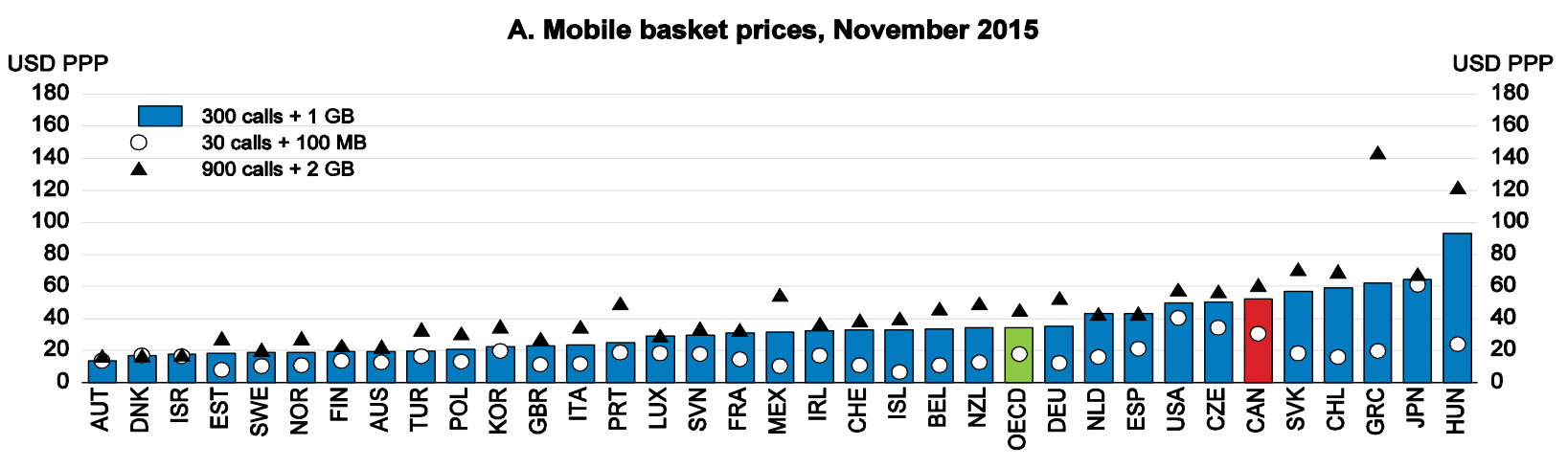

B. Fixed broadband prices, December 2015

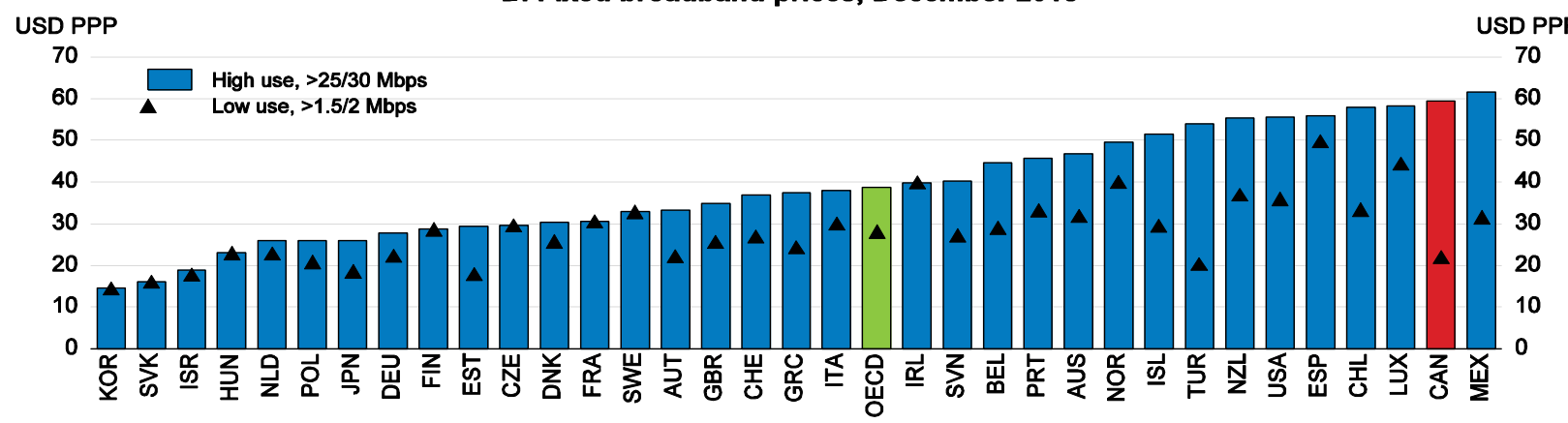

C. Triple- and quadruple-play baskets, April 2014

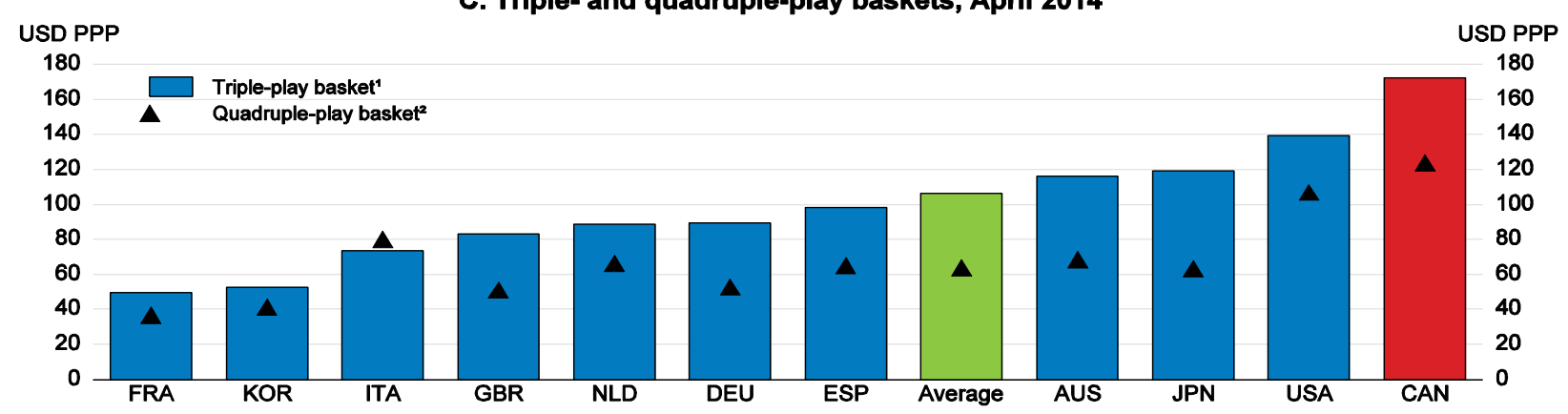

1. 30 Mbps download speed and $200 \mathrm{~GB}$, unlimited fixed line calls, premium pay-television including sports and movies.

2. At least $10 \mathrm{Mbps}$ broadband download speed and $25 \mathrm{~GB}$ capacity, fixed line connection, basic pay-television and 30 call mobile basket.

Source: OECD (2015), OECD Digital Economy Outlook 2015, with updates. 
Figure 11. Telecommunications subscriptions

A. Wireless broadband subscriptions per 100 inhabitants, June 2015

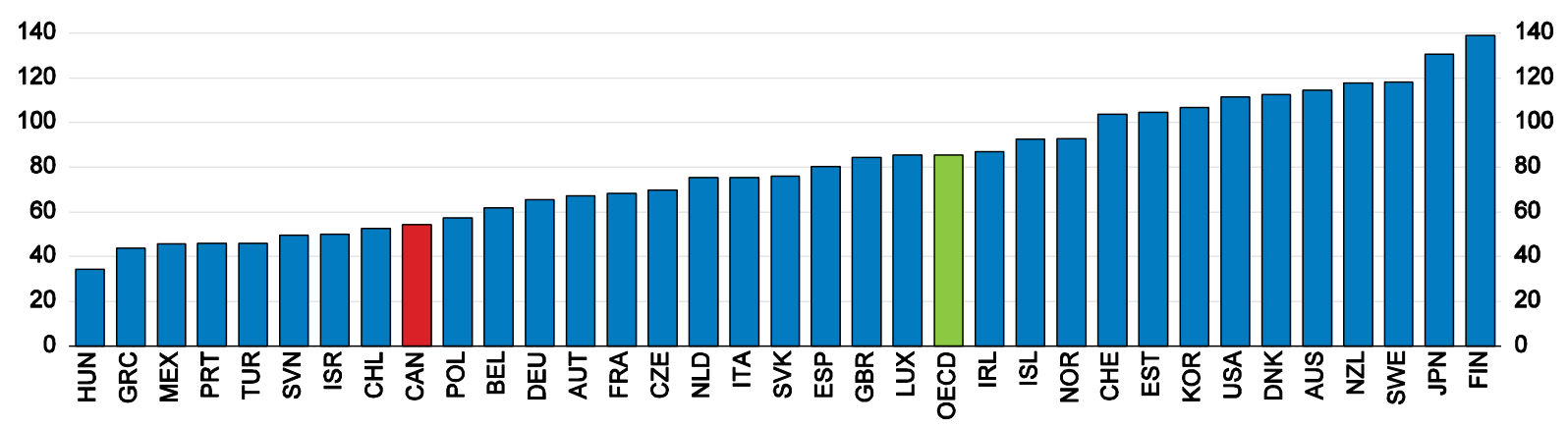

B. Fixed (wired) broadband penetration by speed tiers, ' June 2014
Subscriptions per 100 inhabitants

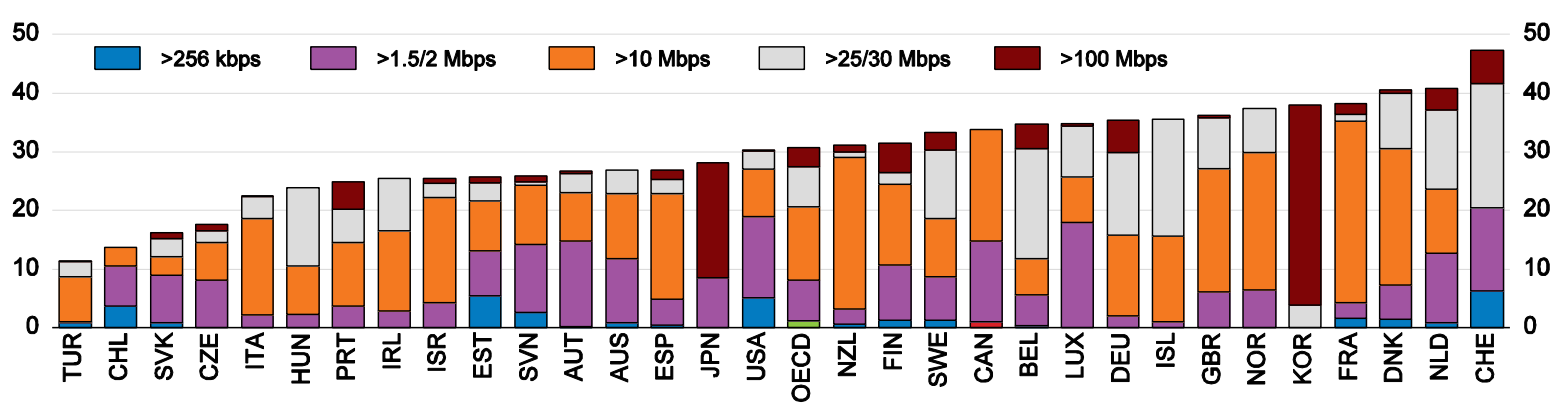

C. Cellular mobile penetration, 2013

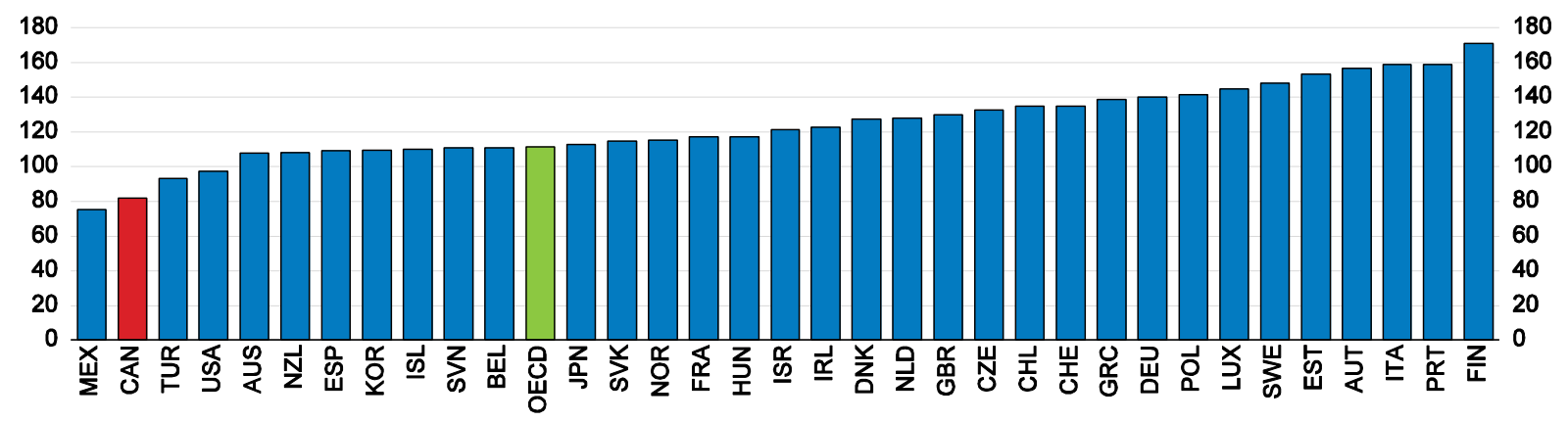

1. For Japan, data are OECD estimates with the tiers lower than $100 \mathrm{Mbps}$ unseparated. They may also include an auxiliary portion of the top tier. For Korea, 10\% refers to below $50 \mathrm{Mbps}$ and $90 \%$ refers to above $50 \mathrm{Mbps}$.

Source: OECD (2015), OECD Digital Economy Outlook 2015, with updates.

The government's focus on increasing competition in mobile telephony in recent years has largely concentrated on easing entry barriers to facilitate a fourth national mobile carrier and on lowering consumer switching costs. Measures to increase consumer mobility (thereby boosting demand elasticities and hence cutting prices) through the 2013 Wireless Code included reducing contract periods to two years (previously most had three-year terms), restricting the practice of locking phones to prevent their use with competing service offerings and limiting early exit charges. Efforts to encourage a fourth national carrier have included: implementing spectrum caps; establishing new roaming and tower-sharing policies; easing foreign ownership restrictions for small entrants (discussed below); limiting the transfer of mobile spectrum to incumbents; and regulating wholesale roaming rates charged by the three large providers. In addition, in June 2015, as a condition for the transfer of spectrum from Mobilicity, in receivership, and 
unused spectrum owned by Shaw Cable Systems to Rogers, the government required Rogers to transfer 25 spectrum licences free of charge to Wind Mobile. Wind was subsequently acquired by Shaw after the Competition Bureau gave regulatory approval (potentially Canada's fourth national carrier).

In all OECD countries there are at least three mobile network operators (MNOs) that compete nationally, with some countries having four or five facilities-based networks nationally or in the same region. Countries with a larger number of MNOs tend to have more competitive and innovative service offerings (OECD, 2014d). Moreover, new entrant prices are on average 26 to 50\% less than average incumbent prices in Canada, depending on the relevant service category (Wall Communications Inc., 2015). Elixmann et al. (2015) found no linkage between consolidation or higher concentration in mobile markets and investment for eight European countries, Australia, Japan, Korea and the United States. Their study suggests that investment tends to follow long-term investment cycles that appear to be largely unrelated to developments in market structure in the countries assessed. Despite this, however, it will be important to monitor the impact of these efforts to encourage a fourth MNO on investment and the quality of mobile networks.

Broadband internet access is considered an important driver of productivity and competitiveness (Nordås and Rouzet, 2015). Despite high prices, Canadian per capita internet subscriptions are comparatively high. Canada has experienced growth in fibre connections in recent years, as regional incumbent telephone companies have shifted from investing in fibre-to-the-node/VDSL to fibre-to-thehome. The adoption rate of fibre access remains low compared with most OECD countries (OECD, 2015b). This may reflect the policy framework and extent of competition; however, it may also reflect long geographical distances and lower population densities.

While there is no one-size-fits-all regulatory framework that best encourages competition in broadband (OECD, 2011), Canada has focused on facilities-based competition among incumbent telecommunication service providers and cable companies and requires wholesale network access for internet service providers (ISPs) on a regulated long-run average incremental cost basis to encourage retail competition. In addition, the CRTC has implemented measures to ensure that non-price access measures are not used to discriminate against retail competitors, including requiring that secondary ISPs are offered the same high speeds as their own ISPs and ensuring congestion management practices do not throttle secondary ISPs' traffic. In 2015, guaranteed access for secondary ISPs was extended to fibre optic cable to the premises and ultra-high-speed cable networks. However, it no longer applies to incumbents' transport lines between areas, only to local lines. Therefore, secondary ISPs are now required to construct or negotiate access to incumbents' or another company's transmission lines. Overall, with wholesale rates that provide a reasonable rate of return, the incumbent telecommunication carriers are likely to continue to invest in fibre access in order to compete with cable networks.

With the digitalisation of media through the Internet and mobile devices, broadcasting regulations are becoming increasingly outdated, and the distinction between telecommunication providers, regulated under the Telecommunications Act, and broadcasting distribution undertakings (BDUs), primarily cable and satellite providers, regulated by the Broadcasting Act, are becoming blurred. Following a 1999 assessment, the CRTC felt that there was a significant amount of Canadian new media content (including video games, e-commerce and other Internet-related services) and chose to exempt them from broadcasting regulation to encourage innovation, a decision that was upheld in 2009. While the CRTC eased content rules for daytime television and for most specialty channels in March 2015 (CBC, 2015), BDUs remain at a competitive disadvantage relative to new media, as they are required to abide by remaining Canadian content rules and make financial contributions towards the creation of Canadian content. Typically these contributions amount to a minimum of 5\% of their gross annual revenues derived from broadcasting activities (Dewing, 2011). To level the playing field between BDUs and new media, the government could consider subsidising Canadian content directly through general taxation. 
Recent regulatory actions in broadcasting have focused on encouraging consumer switching by banning 30-days-notice cancellation policies (effective January 2015) and on plans to unbundle channel offerings. Since March 2016 the CRTC has required entry-level service to be provided at a cap of CAD 25/month and to have unbundled channels (pick and pay) or a choice to build or choose preassembled small packages, with full rollout by December 2016 (with both unbundled channels and small packages required as of this date). The need for the CRTC to step into the broadcasting market to regulate BDU offerings to drive lower priced basic service and unbundling channels/packages may highlight the lack of effective competition, particularly given vertical integration, despite the broadened alternatives provided by media digitalisation.

Overall, while Canada's high telecommunication service prices may reflect greater investment and quality, they may also highlight concerns over the level of competition. Canada's foreign ownership limits in telecommunications (and broadcasting) are some of the OECD's most restrictive (Figure 12), which may reduce competition and access to finance and slow the diffusion of new technologies. Nordås and Rouzet (2015) have shown that there is a strong relationship between performance indicators in telecommunication services, including lower subscription rates, and sectoral trade restrictions. Following the lifting of restrictions for small carriers in 2012, the remaining restrictions generally require that foreign interests hold no more than 46.7 percent of voting equity in any facilities-based telecommunications carrier or BDU and that the board of directors be at least 80 percent Canadian, but they do not apply to companies that resell telecommunication services. The ownership restrictions no longer apply to providers whose revenues are less than $10 \%$ of the total Canadian telecommunication market. However, as such companies are prevented from bundling telecommunication services with broadcasting, where foreign ownership restrictions still apply, barriers to entry are probably still high.

Figure 12. Foreign entry restrictions in telecommunications are high in Canada Index from 0 (open) to 1 (closed), 2015

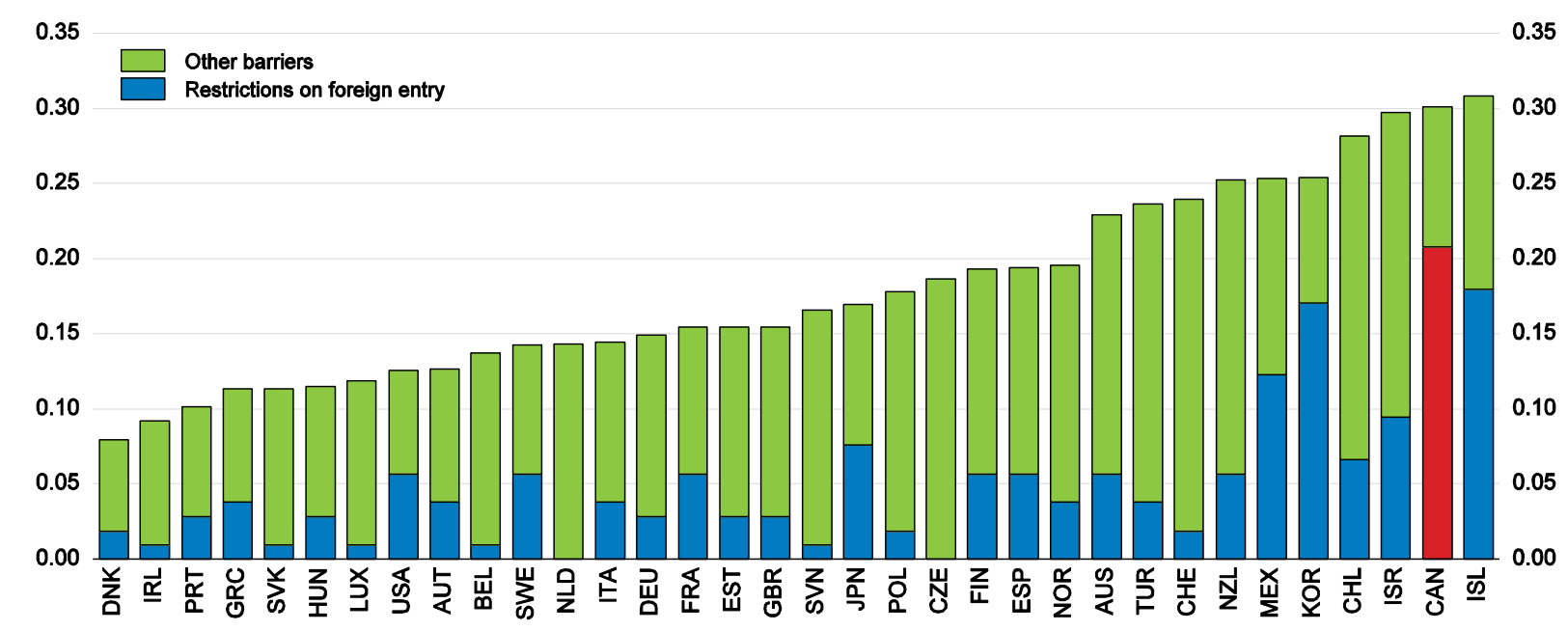

Source: OECD, Services Trade Restrictiveness Index database.

Removing foreign ownership restrictions could heighten the level of competition in telecommunication services and broadcasting, leading to lower consumer prices. Rouzet and Spinelli (2015) show that eliminating these restrictions in telecommunications could reduce price-cost margins by 2 percentage points from $26 \%$, yielding tangible gains for consumers and downstream firms. To transition to a more open investment climate, the government could consider further liberalising entry in telecommunication services and liberalising entry in broadcasting, as recommended by the 2005-06 Telecommunications Policy Review Panel. Given large structural entry barriers, it may be necessary to allow foreign acquisitions of smaller broadcasters (i.e. those with less than $10 \%$ market share). Following 
this transition period, foreign entry should be liberalised completely (including acquisitions), though foreign investments would remain subject to the Investment Canada Act. While foreign ownership restrictions in broadcasting reflect in part efforts to safeguard, enrich and strengthen the nation's cultural, political, social and economic fabric (Dewing, 2011), these cultural goals would be better protected by other means than ownership restrictions.

Recommendations to improve competition in telecommunications and broadcasting
- Remove foreign ownership restrictions in telecommunications and broadcasting, if necessary in a two-
stage process. Protect cultural goals in broadcasting using other means than such restrictions.
- To level the playing field between cable and satellite companies and new media, consider subsidising
Canadian content through general taxation.

\section{Transportation}

\section{Air transportation}

Canada's airline industry was deregulated in 1987 with the passage of the National Transportation Act. The Act required airlines providing domestic service to be Canadian owned and controlled. Given Canada's geographical size, airlines play an important part in the movement of people, time-sensitive cargo and goods to northern and remote regions, and few transport alternatives exist in many cases, except over short distances. As a result, passenger air travel is generally considered as a separate market from other forms of transportation modes (OECD, 2014b). Consequently, the failure of one of the two large national carriers (Canadian Airlines International) and its merger with Air Canada in 2001 gave rise to competition concerns. Various measures were recommended by the Competition Bureau to ensure that anti-competitive practices were limited following its acquisition by Air Canada. This included provisions that dealt with predation in the airline industry and the pre-emption of facilities-based and other exclusionary conduct. Legislative amendments also empowered the Commissioner to issue temporary orders to prohibit domestic airlines from engaging in anti-competitive conduct (OECD, 2014b). Since then, a second national carrier, WestJet, which provides domestic service and international flights, has emerged. Other smaller but important airlines have entered as well (including Porter, Transat and Sunwing) that offer international and domestic flights and others offering only domestic flights. There were also several attempts at establishing other carriers, but these have failed.

During the initial period of deregulation prior to 2000, Canadian prices for domestic air travel were relatively flat in real terms (OECD, 2004; FRBSF, 2002). However, since 2000 real domestic air fares have fallen more in Canada than in the United States (Figure 13). Despite this, air fares for similar routes from US airports near the border have tended to be lower than from Canadian airports (Gill, 2012). High transportation costs penalise travel and may erode business competitiveness and reduce the attractiveness of Canada as a tourist destination. Relatively high prices may justify concerns over competition, including elevated barriers to entry and the role of taxes and fees, along with lower passenger densities in Canada, in eroding cost competitiveness. Past research has shown that competition from low-cost carriers has resulted in lower prices in Canada (CTARP, 2001), suggesting that reducing barriers to entry would yield lower prices for consumers and underpin the broader competitiveness of Canadian firms.

Structural barriers to entry into air transport (airlines and airports) (e.g. the expense of investing in or leasing aircraft, booking systems, slots, access to airport facilities including check-in facilities and gates, etc.) probably limit the amount of competition in a liberalised market (OECD, 2014a). These barriers have probably been amplified by other regulatory and strategic barriers. Sectoral regulation in the transportation 
sector is only slightly more restrictive than the OECD average (Figure 14), as Canada participates less in regional agreements, such as the European Union's Common Aviation Area, that facilitate air travel and competition in the sector; however, it has been very active in negotiating Air Service Agreements (ASAs) and open skies-type agreements to facilitate air travel.

Figure 13. Real average domestic air fares'

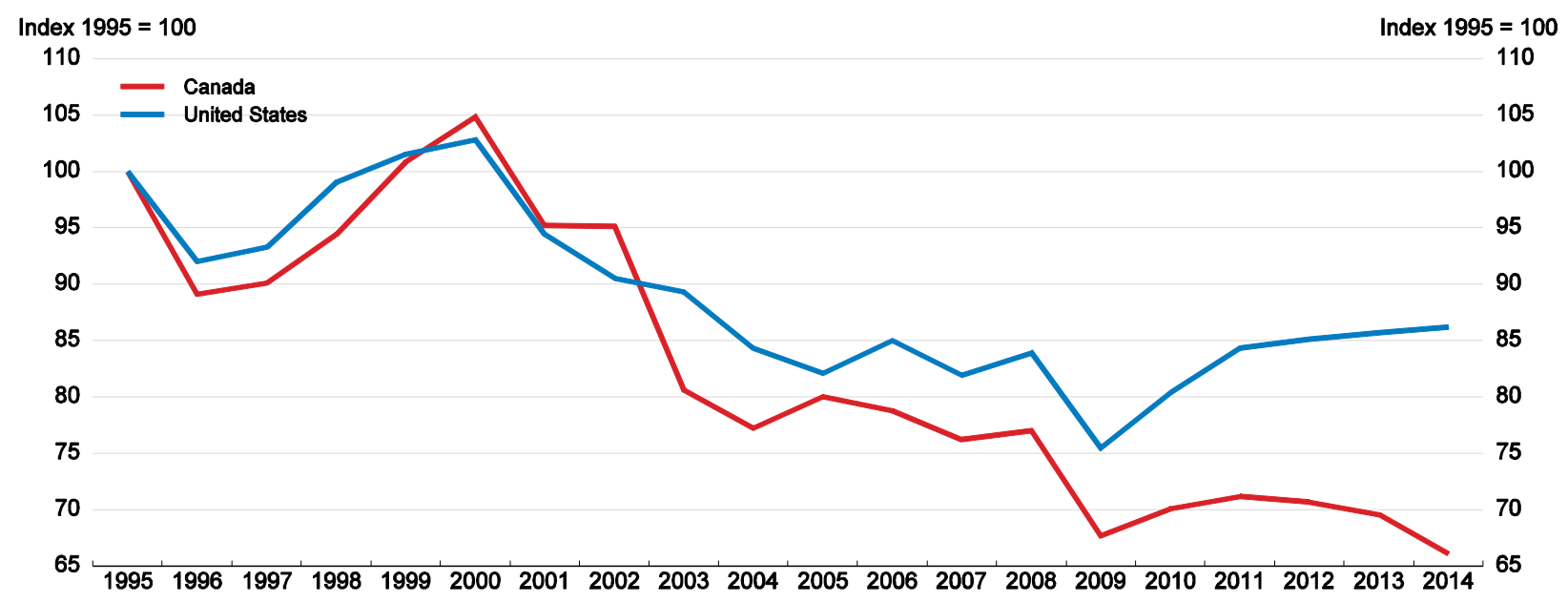

1. Does not take into account possible changes in average flight length. Average domestic air fares have been deflated by the respective total consumer price indices.

Source: Statistics Canada, Tables 401-0004 and 326-0021; US Bureau of Transportation Statistics; OECD calculations.

In particular, Canada's Blue Sky Policy, adopted in November 2006, calls for a proactive approach to negotiating ASAs, including establishing reciprocal open skies-type agreements (similar to that negotiated with the United States in 2005) when it is in Canada's overall interest to do so. In setting its negotiating priorities, Canada consults a range of stakeholders, including air carriers, airport authorities, provincial and territorial governments, and others (e.g., business and tourism associations). As part of this process, consideration is given to issues such as the likelihood of liberalisation leading to new Canadian and foreign carrier services; the size and maturity of the air transportation markets under consideration and potential for future growth; Canada's international trade objectives; safety and security issues; foreign government requests and foreign relations; and bilateral irritants and disputes. Canada has negotiated new or expanded ASAs with over 80 countries, covering $71 \%$ of Canada's international passenger traffic and $94 \%$ of Canada's overall international two-way merchandise trade (Transport Canada, 2015). However, if 'modified sixth freedom agreement rights', currently excluded from Canada's open skies agreements, were granted, this would increase competition and choice. For example, a US carrier (for reasons of geography, the United States is the only partner with whom modified sixth freedom rights would be operationally feasible) could fly from one Canadian airport to another through a US destination. Furthermore, competition could be strengthened by pursuing deeper continental integration through a common aviation area, as in the European Union, and placing a greater priority on consumer and non-airline business interests in negotiating ASAs.

Services trade restrictions in air transportation are relatively high in Canada, owing to restrictive foreign ownership limits (Figure 14, Panel B). This results in financing restrictions that may deter entry, raise funding costs for incumbents and lead to a slower adoption of new technology and best practices. To operate domestic air services, carriers are required to have no more than $25 \%$ of their voting equity owned by foreigners. Foreigners may, however, own non-voting equity. Lessening these restrictions by raising the limit to $49 \%$ (of voting equity) for air carriers engaged in international air services, could act to reduce funding costs for airlines and increase competition. In the domestic market eliminating foreign ownership 
restrictions completely and granting rights of establishment (where foreign carriers would be permitted to establish a separate carrier in Canada), as in Australia and New Zealand, could heighten domestic competition and consumer choice. In the longer run, removing foreign ownership limits completely, including on international routes, as in Chile, could further promote competition. This said, easing these regulations can be expected to reduce wage premiums for workers in the sector and may increase job churn (Denk, 2016), which may increase political resistance to reform.

Figure 14. Regulation in the airlines sector

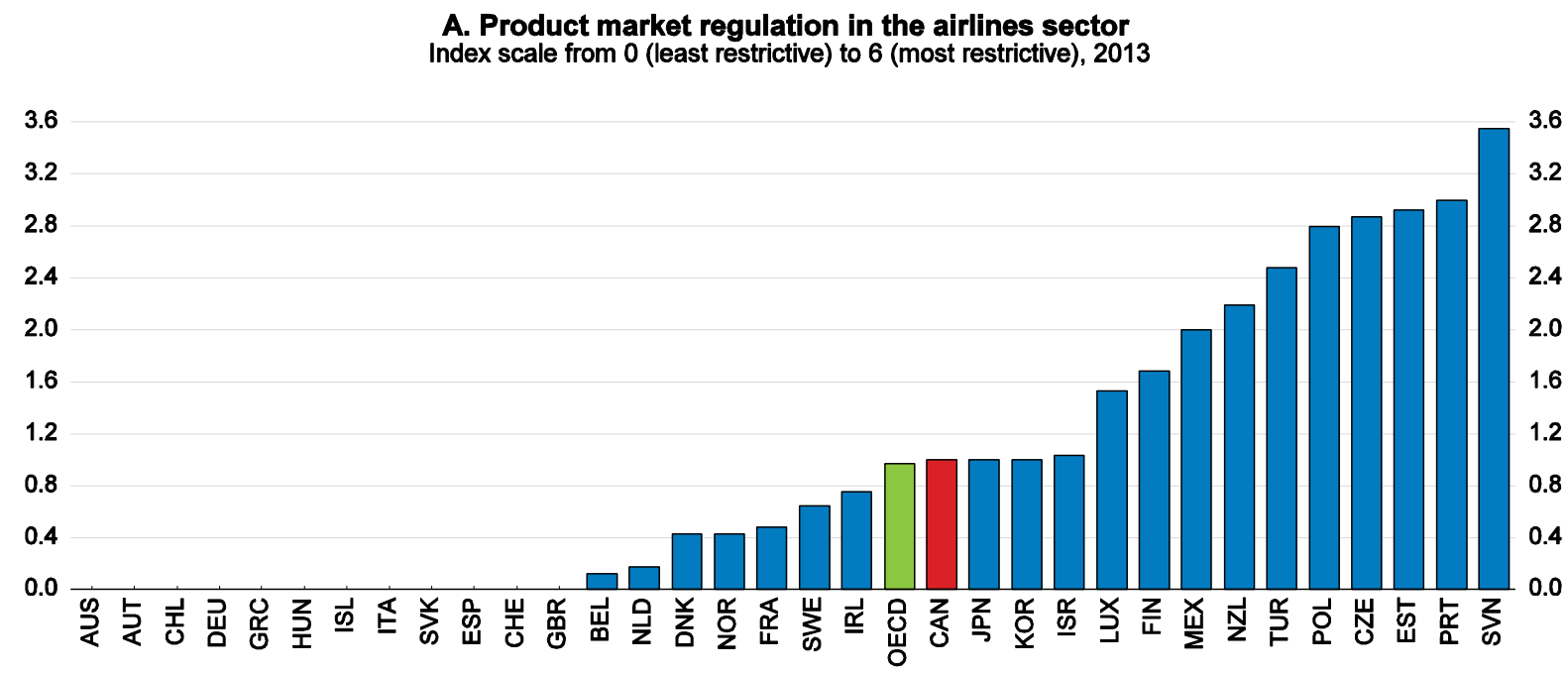

B. Services trade restrictiveness index (STRI) for air transport by policy area Index from 0 (open) to 1 (closed), 2015

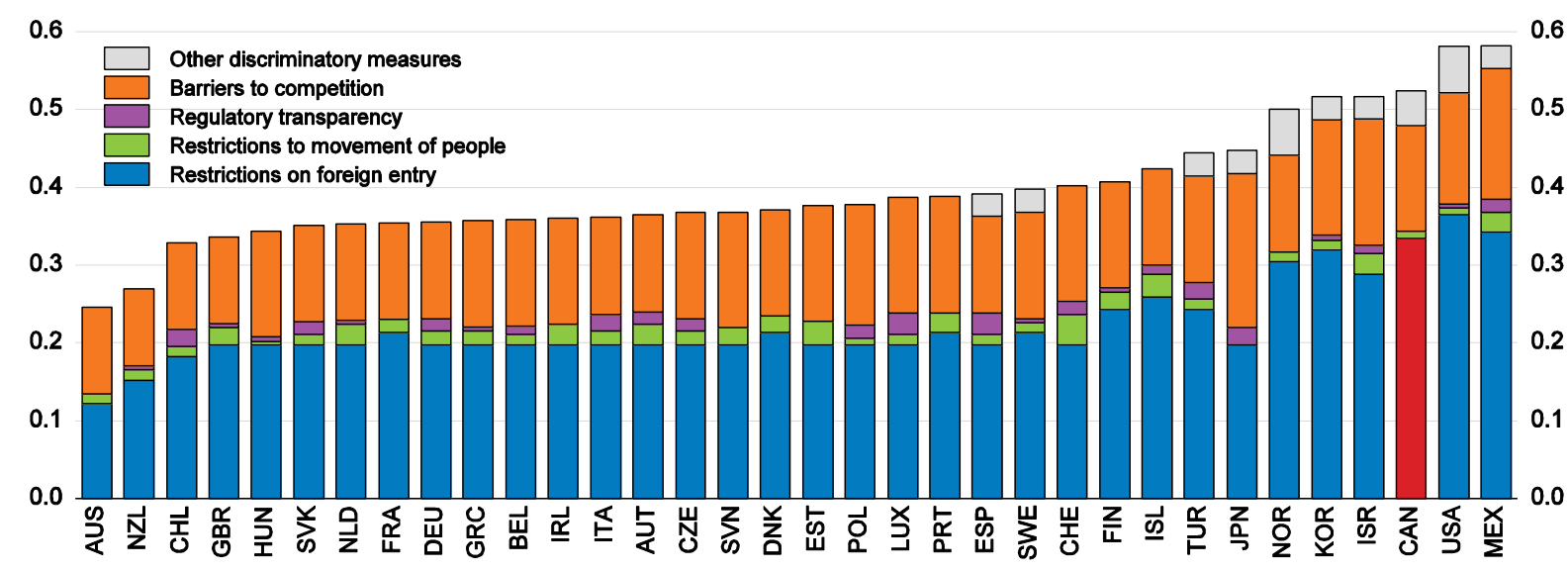

Source: OECD, Product Market Regulation database and Services Trade Restrictiveness Index database.

Structural barriers, such as access to take-off and landing slots, may also limit entry. Moreover, these barriers may be magnified if airport capacity is strained, albeit Canadian airports are not particularly congested, except Toronto Pearson and Vancouver International at peak times. These two hubs play a key role in Canada's hub-and-spoke system, and efficiency at these airports affects the overall system. As in many countries, slots at capacity-constrained Canadian airports are generally allocated based on historical rights, with precedence for new entrants to $50 \%$ of the pool and use-it-or-lose it provisions in place, based on International Air Transport Association guidelines. To facilitate further entry the government could also consider implementing a secondary market for slot allocation, where slots could be freely traded (leased or 
sold) between airlines, with government oversight of the trading mechanism to ensure fair access. Alternatively, broadening congestion-pricing strategies to allocate slots could also lead to increased efficiency in airport use (Madas and Zografos, 2010).

Strategic barriers to entry have also been enacted by airlines, including frequent flyer programmes (FFPs), corporate discount schemes and travel agent arrangements. FFPs may deter competition because they reduce the willingness of customers to switch carriers when faced with higher prices or lower quality, allowing carriers to increase margins as a result. The impact on competition of such programmes may also be magnified by participation in alliances. Norway, for instance, banned SAS's FFP on domestic travel in 2002, given the anti-competitive effects of such schemes, which facilitated entry of a new low-cost carrier. In the early 2000s, Air Canada was also required for a five-year period to sell access to its FFP to other Canadian carriers with less than CAD 250 million in domestic passenger revenues. Ultimately, it spun off Groupe Aeroplan, which later became Aimia, which is neither owned nor controlled by Air Canada. The federal government should assess the extent to which such programmes and discount schemes may be deterring entry. If anti-competitive effects are significant, the government should consider limiting points on certain routes or allowing passengers on new carriers to collect points on incumbents' programmes with compensation from the carrier.

The current structure of the Canadian airport system and associated fees may be harming cost competitiveness (Figure 15). Following the 1994 National Airport Policy, the government transferred smaller local airports to regional entities but retained ownership of the 26 busiest airports, which cover 94\% of all passengers and cargo (SSCTC, 2012), leasing most of them to not-for-profit local Canadian Airport Authorities to manage and operate. While exempt from federal taxes, they must pay ground rent to the federal government, which can represent up to $30 \%$ of their operating budgets (CTARS, 2015). Rent was meant to ensure that the government was made no worse off financially from these transfers. Since 2005 , the rent formula has been increasingly linked to airport revenues. This has probably deterred airport expansion, and its application to revenues rather than profits (allowed under a for-profit airport structure) may have reduced low-margin activities. Dachis (2014) argues that as a result, non-aeronautical revenues are lower at Canadian airports than in many other countries. A 2012 Senate report urged the Canadian government to stop charging rent and transfer Canada's main airports to the authorities that already operate them (SSCTC, 2012). The federal government should assess the impact of the current ownership structure of large Canadian airports on efficiency and cost competitiveness. It should consider dissolving the existing authorities and selling its remaining ownership interests in airports to a private company or companies or to a set of investors. Alternatively, as recommended by the 2014-15 Canada Transportation Act Review, it could convert the existing airport authorities into share capital, for-profit corporations and sell them the airport lands. At a minimum, it should tie airport rents to profits under a for-profit structure for authorities or land values, rather than revenues (including eliminating the progressivity of the tax) to encourage airports to take on alternative revenue streams that would help to lower landing fees. 
Figure 15. Ticket taxes and airport charges

Index of relative cost of access to international air transport services from 0 (lowest) to 100 (highest) ${ }^{1}$

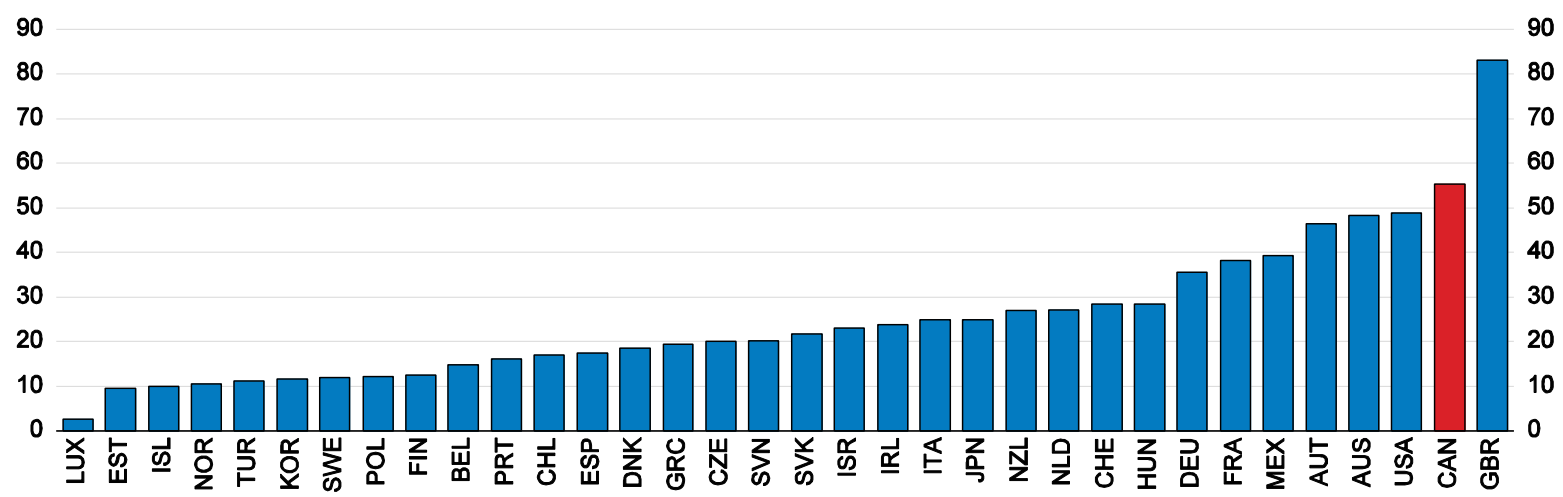

1. Series reversed as 100 minus original series.

Source: World Economic Forum (2015), Travel and Tourism Competitiveness Report 2015.

Overall, Canada's comparatively high airport fees and ticket taxes may be eroding Canadian carriers' cost competitiveness to the extent that they compete with foreign rivals using airports abroad, such as in the United States. While the charges may be minor by themselves, the series of small fees add up to drive a wedge between Canadian and US air fares. One study (Gill, 2012) suggested that roughly $50 \%$ of the difference between carrier costs in Canada and the United States that feed into base fares can be accounted for by fees, fuel prices and taxes. However, this reflects the user-pay principle in Canada, while US infrastructure is not fully funded by user fees and airports are heavily subsidised. Nevertheless, lower US fares have contributed to a leakage of Canadian travellers to nearby US airports. While the recent depreciation of the Canadian dollar has probably reduced this gross outflow of passengers in the last couple of years (no corresponding figures are available in net terms), it is estimated that over 2.5 million Canadians crossed the border to fly from U.S. airports in 2011 (Gill, 2012), reducing output and employment in the sector. A summary of the various charges and fees is provided in Table 3 below, including a comparison with the United States. 
ECO/WKP(2016)46

Table 3. Airport taxes and fees

Taxes and fees

Description and comparison to United States ${ }^{1}$

\section{Included in base fares \\ Airport rent}

Navigation fees

Payments in lieu of municipal taxes (PILTs)

Fuel taxes

\section{Applied to base fares}

Air travellers security charge

Airport improvement fee

Sales taxes
Ground rent is paid by leased airports to the federal government, which are based on a progressive formula tied to revenues. Such rents are not levied in the United States as they are owned and operated by the city or county, though some revenues are used to subsidise public transport in the United States.

Nav Canada charges carriers for the cost of navigation and related services. These charges are limited to cover costs and to maintain reasonable financial reserves. Such charges are partly subsidised in the United States.

Canadian airports are subject to PILTs, while they are not charged in the United States, as airports are typically owned by the municipalities. Federal fuel taxes are not levied on international flights, as is international practice, but are levied by some provincial governments (Manitoba, Nova Scotia, Ontario and Prince Edward Island), which may affect international competitiveness. Most states do not impose aviation fuel tax on international commercial flights. A federal excise tax of 4 cents/litre is also levied on fuel for domestic flights. Taxes levied on domestic flights go to general revenues in Canada, while they are reinvested in aviation infrastructure in the United States.

Covers the full cost of pre-boarding screening of passengers, their belongings and checked baggage as well as security services provided by the Canadian Transportation Security Authority (CATSA). CATSA has been the crown corporation responsible for delivering air travel security in response to the 11 September 2001 attacks. The charge also covers Transport Canada regulations and oversight and Royal Canadian Mounted Police officers on selected domestic and international flights. In the United States, however, security costs are partly government funded. Airport improvement fees are charged by the airports to pre-finance infrastructure investments. Charges vary by airport based on their capital programmes, and there is little oversight of the amount of the charges. Similar charges in the United States (Passenger Facility Charges) tend to be lower (Gill, 2012) and are capped by Congress.

The Goods and Services Tax/Harmonised Sales Tax (GST/HST) is levied on top of base fares and all other charges and fees for domestic air travel, and only GST is levied for air travel to the United States (except Hawaii). Neither the GST nor HST is levied on other international flights.

1. Some offset is provided by fees charged in the United States and not in Canada including the transportation tax, the agriculture fee, the customs fee and the immigration user fee.

Rail

In the rail sector countries have adopted varying combinations of private and public ownership, industry structure (unbundling, licencing or vertical integration) and regulatory measures and rely on varying competitive sources to limit market power (intra- vs. inter-modal) (OECD, 2013). The resulting market structure depends largely on the pre-existing track and geography, along with regulatory and policy interventions. Rail in North American countries is dominated by freight, operates over vast distances and has vertically integrated companies The European Union, on the other hand, tends to be dominated by passenger traffic (particularly in Western Europe) and has moved to introduce vertical separation with varying degrees of success. While greater separation may limit anti-competitive behaviour, reduced investment incentives in rail infrastructure, losses of economies of scope and other inefficiencies may increase operating costs (OECD, 2013).

Canada's railway sector is dominated by two main vertically integrated private railways: Canadian National (CN), privatised in 1995, and the always private Canadian Pacific (CP), though some small regional players exist. In 2013, these two companies accounted for $90 \%$ of the total rail industry based on 
revenues (Transport Canada, 2014). Passenger rail plays a small role in Canada, given its geographical size (though passenger rail is more important in the Quebec-Windsor corridor than in other regions). $\mathrm{CN}$ and $\mathrm{CP}$ operate cross-country rail lines (with the exception of Quebec for $\mathrm{CP}$, where it has no rail line) on a commercial basis. Legislative and regulatory provisions to promote increased railway competition, such as those pertaining to regulated running rights (when other operators are granted access to another railway's track network) and interswitching (when a shipper has cars picked up by the railway to which it is closest and has them transferred to another railway at regulated rates), have been put in place. The Canadian rail system has performed well, with falling freight rail rates (in real terms), as increases in tonne kilometres (a measure of freight shipped) have outpaced total revenue gains since deregulation in the 1980s and 1990s (Figure 16, Panel A). Real operating margins have improved since the late 1990s owing to cost containment (Panel B), and labour productivity has also shown steady gains since deregulation (CPCS, 2014; ITF, 2014). Overall, Canada's freight rates are low by OECD standards (Panel C).

Figure 16. Railway performance and rates

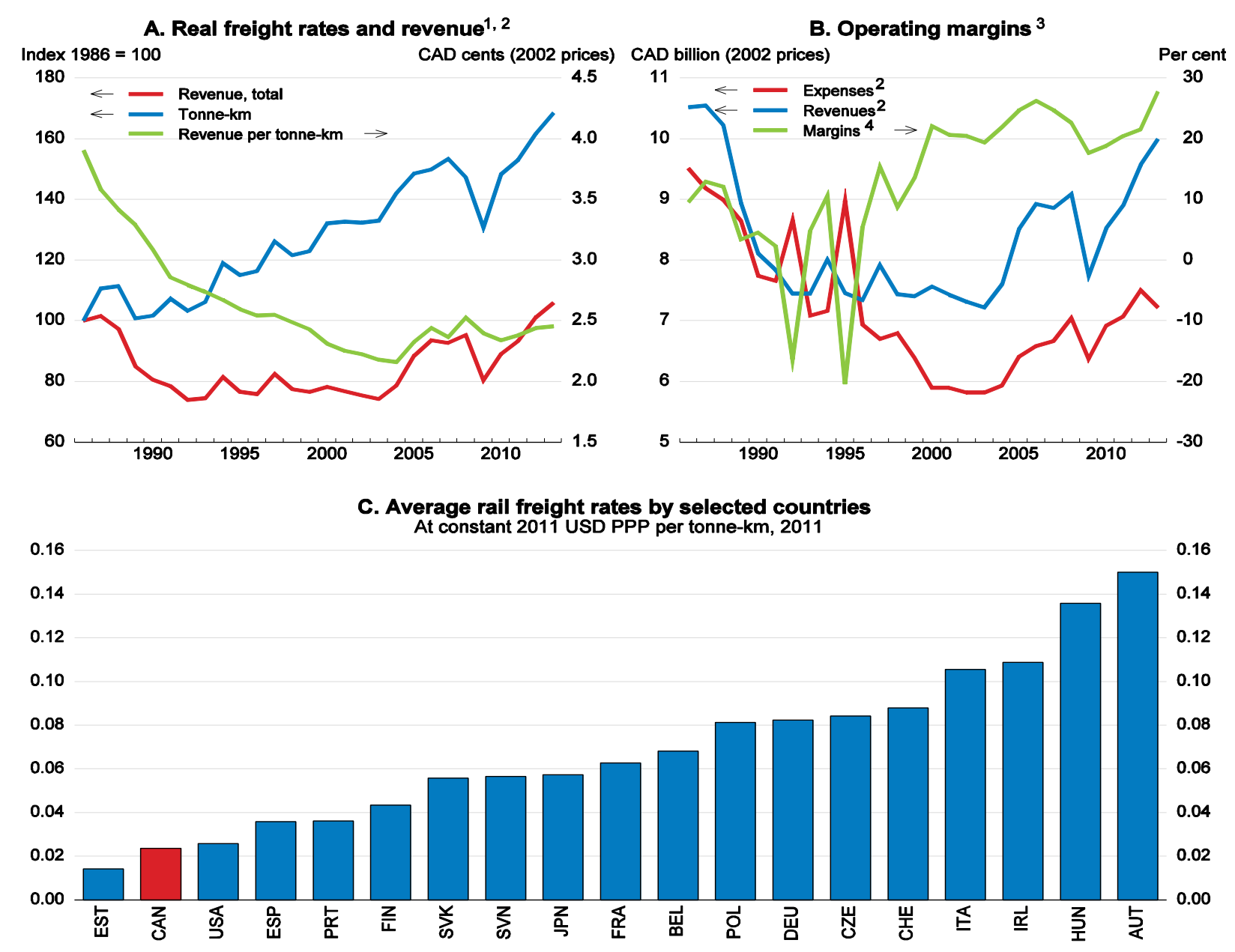

1. Including Canadian National and Canadian Pacific.

2. Deflated by the CPI.

3. Data include freight and non-freight activities for Canadian National, Canadian Pacific and VIA Rail.

4. The operating margin is calculated as the share of net rail operating income in operating revenues.

Source: Statistics Canada; OECD calculations; L. S. Thompson (2014), "What is Rail Efficiency and How Can It Be Changed?", ITF Discussion Paper 2014-23, prepared for the Roundtable Efficiency in Railway Operations and Infrastructure Management, 18-19 November 2014. 
A high degree of overlap exists between CN's and CP's networks. Rail companies compete with each other for more than $40 \%$ of point of origin to point of delivery rail traffic, while roughly $61 \%$ of shippers (excluding grain) surveyed for the 2001 Canadian Transportation Act Review mentioned having access to alternative railways (InterVISTAS Consulting, 2003). These assessments exclude the impact of the increase in interswitching to 160 kilometres from 30 kilometres for commodity shipments (including grain) in the three Prairie provinces, which was put in place in 2014 (see below). Inter-modal competition may exist over short distances, including competition from trucking, but over long distances few cost-effective alternatives exist. The absence of road pricing combined with the commercial structure of freight shipping (such that shippers are implicitly charged the full cost of rail infrastructure) may bias the freight transport system against rail in favour of trucking over these shorter distances.

As the rail sector is highly concentrated, several legislative and regulatory measures have been put in place to encourage competition and ensure service quality (Table 4). While many of the provisions have been used sparingly, their availability is viewed as encouraging competition and efficient negotiations. Expansion of open access or vertical separation should be assessed with caution, given likely negative effects on efficiency, cost and investment incentives. For instance, Ivaldi and McCullough (2004) estimated that an integrated freight railroad in the United States could have a 20-40\% cost advantage over a vertically separated alternative.

Table 4. Regulations to facilitate competition in the Canadian rail sector

\begin{tabular}{|c|c|}
\hline Measure & Description \\
\hline Interswitching provisions & $\begin{array}{l}\text { A shipper is entitled to have cars picked up by one railway and have them transferred to another } \\
\text { railway, provided the shipper's location is within a } 30 \text { kilometre radius from an interchange point. } \\
\text { Fees for interswitching are regulated by the CTA and are based on estimated variable costs plus a } \\
\text { contribution to fixed costs. Following the } 2014 \text { Fair Rail for Grain Farmers Act, the interswitching } \\
\text { radius for commodities supplied by the western provinces of Alberta, Saskatchewan and Manitoba, } \\
\text { was increased to } 160 \text { kilometres (discussed further below). Such provisions are set to expire in } \\
\text { August } 2016 \text {. }\end{array}$ \\
\hline $\begin{array}{l}\text { Competitive line rates } \\
\text { (CLRs) }\end{array}$ & $\begin{array}{l}\text { Facilitates the ability of a shipper to have more than half of the hauling of freight to a final destination } \\
\text { performed by one or more other railways. Shippers can request the railway to provide initial hauling } \\
\text { according to a CLR where applicable. The CLR is based on relevant regulated interswitching rates } \\
\text { and revenue the railway generates for moving similar commodities over similar distances. CLRs } \\
\text { established by the CTA are valid for } 1 \text { year, unless the shipper and railway agree to a different term. }\end{array}$ \\
\hline Running rights & $\begin{array}{l}\text { Enables one railway to run over the tracks of another. Where running rights cannot be negotiated by } \\
\text { the railways, the CTA can grant rights under certain conditions. These include the consideration of } \\
\text { public interest, pre-establishment of service agreements with shipper(s) and evidence of market } \\
\text { abuse or failure, along with corresponding evidence of how such rights would improve competition. } \\
\text { Compensation is required based on mutually agreed rates or rates established by the CTA. }\end{array}$ \\
\hline Final offer arbitration & $\begin{array}{l}\text { Enables a shipper who is dissatisfied with the rate or rates charged by a carrier or conditions } \\
\text { associated with the movement of goods and cannot reach an agreement with the carrier to submit } \\
\text { the matter in writing to the CTA for final offer arbitration. To provide incentives for parties not to put } \\
\text { forward extreme positions, the arbitrator is not permitted to adjust either offer but must rather select } \\
\text { one or the other. }\end{array}$ \\
\hline $\begin{array}{l}\text { Level of service } \\
\text { provisions }\end{array}$ & $\begin{array}{l}\text { Places an obligation on railways to provide adequate and suitable service on the payment of a } \\
\text { lawfully payable rate. Shippers can complain to the CTA, which must investigate and make a } \\
\text { determination within } 120 \text { days. As of } 2013 \text { new provisions were added to the Transportation Act to } \\
\text { allow shippers to seek binding arbitration if they cannot reach an agreement with railways through } \\
\text { negotiations. }\end{array}$ \\
\hline
\end{tabular}

Regulation in the railway sector in Canada is fairly liberal relative to other OECD countries (Figure 17). However, several measures have been put in place to facilitate access and protect captive shippers, particularly for western grain shipments. The Canadian government has capped revenues that $\mathrm{CN}$ and $\mathrm{CP}$ can earn from shipping western grain in any crop year to non-US or non-Canadian-Prairie locations based on the volume and length of the haul (adjusted for input price inflation) since 2000 (Maximum Revenue Entitlement). This is distortionary and could induce rail companies to push their cost onto other goods or commodities and may reduce the incentives for rail companies to move grain. Moreover, some crops, such as chickpeas and soybeans, which have seen increased production in Western Canada do not fall under the 
Maximum Revenue Entitlement, which may distort production patterns. These revenue caps also induce efficiency losses, including discouraging rail companies from making use of container traffic capacity for specialty grains, as it is more costly and revenue caps would be reached more quickly (Prentice and Parsons, 2015). In addition, they reduce incentives for investing in the network, including acquiring more efficient hopper cars to replace the ageing stock (see below).

Figure 17. Sectoral regulation in the rail sector

Index scale from 0 (least restrictive) to 6 (most restrictive), 2013

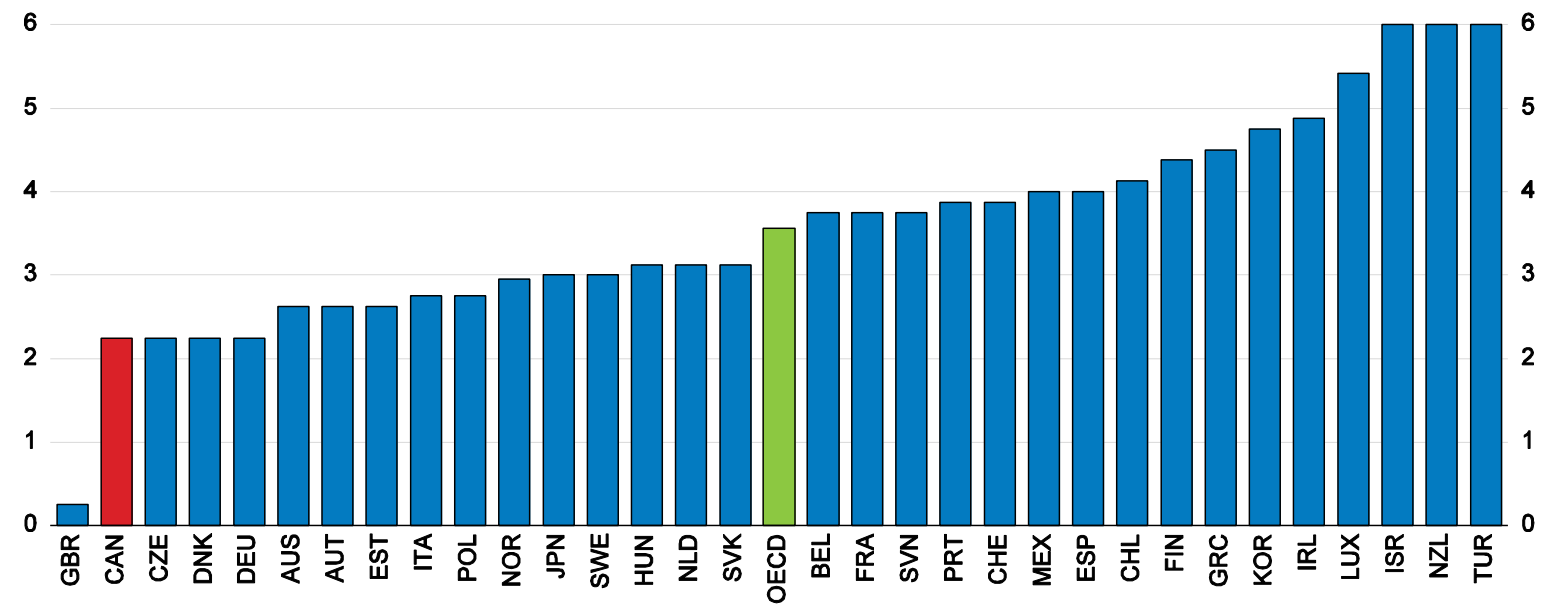

Source: OECD, Product Market Regulation database.

In 2014, as part of the Fair Rail for Grain Farmers Act, the radius for interswitching provisions was expanded to 160 kilometres (from 30) specifically for commodities supplied in the three Prairie provinces, in part to increase rail options for grain farmers. The CTA estimates that the expanded interswitching radius raises the number of grain elevators having access to more than one railway from 48 to 261 (CTA, 2014; Schulman, 2014). These provisions will expire unless renewed by August 2016. The expansion of regulated rates through greater interswitching areas increases (non-reciprocal) access to US rail companies and may reduce investment incentives. In order to make a well informed decision in August it will be important to assess the net benefits of this policy, including its impact on efficiency and investment outcomes, including whether the provisions are necessary for all commodities and should be applied only to the Prairie provinces. Furthermore, to ensure that all interswitching rates reflect actual costs, the CTA should set rates annually and not only when the Railway Interswitching Regulations are reviewed, as recommended in the 2014-15 Transportation Act Review.

Additionally, as part of the Fair Rail for Grain Farmers Act, the federal government maintains the option to impose mandatory volume requirements if the grain supply chain compromises farmers' livelihoods, the economy or Canada's international reputation as a reliable shipper. Such volume requirements were in effect in the year to March 2015. The government also retains ownership of some grain hopper cars, which were purchased in the 1970s and 1980s to ship regulated grains. While rail companies have been paying to upgrade these cars to extend their useful life, the majority of them will need to be replaced over the next 10-15 years. Moving to a more competitive structure for the movement of grain would allow rail companies to invest commercially in an upgraded fleet and avoid similar issues of low investment rates and need for government support.

There is a considerable gap between the average freight rate applied to grain and non-grain shipments by both CP and CN (Figure 18). Furthermore, in 2012-14 CP's average grain shipment rates in Canada 
were $8 \%$ below those in the United States. Indeed, comparing CP's average grain freight rates in Saskatchewan to those just across the border in North Dakota, which may represent conditions similar to those in Canada but without a regulatory revenue cap, suggests that Canadian grain rates may be $14 \%$ below commercial levels (Cairns, 2015). Overall, to reduce distortions and encourage more investment, renewal and efficiency of the rail network, revenue caps on grain shipments should be eliminated.

Figure 18. Grain and non-grain freight rates

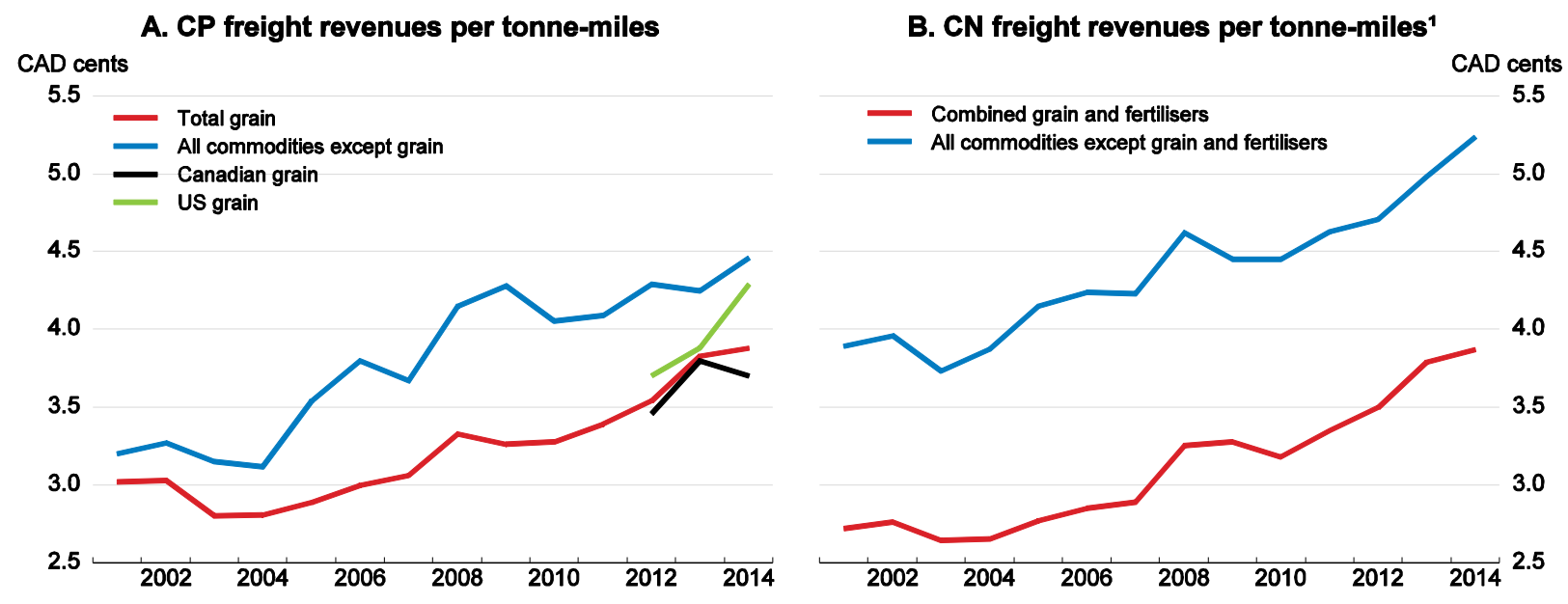

1. Data for $\mathrm{CN}$ also includes fertiliser shipments, but these shipments were small in comparison to grain (18\% of combined grain and fertiliser revenues in 2014).

Source: Canadian Pacific and Canadian National Railways, Annual Reports, various years; OECD calculations.

\section{Air transport}

\section{Recommendations to improve competition in transportation}

- Eliminate foreign ownership restrictions in air transportation on domestic routes, and raise them on international routes to $49 \%$ (the threshold required for international air service agreements under IATA rules).

- $\quad$ Consider seeking deeper integration within North America to establish a common aviation market.

- Assess the impact of the current ownership structure of large Canadian airports on efficiency and cost competitiveness. Consider selling the largest airports to one or more private companies or set of investors. Alternatively, convert existing airport authorities into one or more for-profit corporations and sell them airport land. At a minimum, tie airport rents to profits or land values rather than revenues by moving towards a for-profit structure for airport authorities.

- Investigate the extent to which the current slot allocation system at constrained airports is reducing competition and system wide-efficiency. Consider implementing a more competitive process for slot allocation, such as establishing a secondary market, or broadening congestion-based pricing.

\section{Rail transport}

- Eliminate revenue caps on western grain shipments by rail.

- Determine whether the expanded interswitching zone for Prairie provinces' commodity shipments has led to net benefits for the economy; otherwise allow the provisions to lapse in August 2016.

\section{Easing interprovincial barriers to trade and labour mobility}

While interprovincial tariff barriers are forbidden by the Canadian constitution and Canadians have the right to live and work anywhere in the country, the existence of non-tariff interprovincial barriers 
reduces trade and labour mobility and weakens efficiency and productivity. If these barriers contribute to a smaller scale of production and retailing, the result may be a loss of competitiveness abroad and higher prices domestically. Overlapping federal, provincial and territorial regulatory responsibility in many economic policy areas has enabled the emergence of numerous direct and indirect non-tariff interprovincial barriers. Following a push in the mid-1980s to reduce them, the Agreement on Internal Trade (AIT) took effect in July 1995.

\section{The Agreement on Internal Trade (AIT)}

The principles of the AIT are to: restrict the establishment of new barriers to internal trade and to facilitate the movement of persons, goods, services and investments in Canada; treat persons, goods, services and investments equally, regardless of where they originate; reconcile standards and regulations; and ensure that administrative policies operate to provide for the free movement of persons goods, services and investments within Canada. Exemptions to these principles are permitted where it can be demonstrated that they are to achieve a legitimate objective, do not unduly impair access and are not deemed to be a disguised restriction on trade. The AIT includes provisions covering procurement, investment, labour mobility, consumer-related measures and standards, agriculture and food products, alcoholic beverages, natural resources processing, communications, transportation and environmental protection. Since its establishment, 14 amendments have been made to strengthen some of its aspects, including measures to further liberalise labour mobility (2009) and agricultural trade (2010), and to strengthen the dispute resolution process (2012 and 2015).

Negotiations to modernise and update the AIT began in late 2014. The 2015 federal budget announced the creation of an internal trade promotion office within Innovation, Science and Economic Development Canada to support the AIT negotiations and act as a federal hub for research and analysis. In addition, the development of an internal trade barriers index as announced in the 2014 budget should help to better understand trade barriers and prioritise reforms.

The AIT is widely believed to have contributed to the removal of a range of interprovincial barriers in Canada and, along with subsequent amendments, to have improved the flow of people and goods across borders (Public Policy Forum, 2013). However, its overall framework, dispute resolution mechanisms and the absence of agreements in particular sectors (i.e. energy) are reducing its effectiveness. Furthermore, the slow pace of AIT reform has led to several fragmented trade enhancement arrangements on a regional basis outside of the AIT (Box 2). Annual cost estimates of the impact of these internal barriers range widely. The Public Policy Forum (2013) placed these barriers at CAD 3 billion to 49 billion (0.2 to $2.5 \%$ of GDP). However, most estimates are in the middle to lower end of this range, though Albrecht and Tombe (2016) is a notable exception.

The AIT uses a positive list approach in which only rules that are described in the Agreement apply, contrary to many modern free trade agreements, which employ a negative list approach and focus on removing all barriers subject to negotiated exemptions. This latter approach may lead to shorter negotiations and a transparent list of barriers that may be targeted in the future. Moreover, such an agreement would be more dynamically efficient, as new sectors or areas would be automatically covered. This framework is used by the New West Partnership Trade Agreement (NWPTA), which was signed between the provinces of Alberta, British Columbia and Saskatchewan, and recent international trade agreements (e.g. the Comprehensive Economic and Trade Agreement between Canada and the EU). 


\section{Box 2. Summary of internal trade agreements outside of the AIT}

To build on the AIT, several regional internal trade agreements have been signed to facilitate trade between the provinces. Many have focused on facilitating trade through the harmonisation of regulations and streamlining processes. A summary of some of these agreements and key differences relative to AIT are provided below.

- New West Partnership Trade Agreement (NWPTA): signed in 2010 between Alberta, British Columbia and Saskatchewan, this agreement builds on the 2006 Trade, Investment and Labour Mobility Agreement between Alberta and British Columbia. The NWPTA follows a negative list approach, establishing a framework to remove barriers in all sectors of the economy that relate to trade, investment or labour mobility. It also commits these three provinces to full mutual recognition or reconciliation of their rules in these areas and includes additional clauses to facilitate international trade, investment and talent development, and joint procurement initiatives to increase competitiveness. It includes lower procurement thresholds for the NWPTA to apply than the AIT and facilitates labour mobility for a longer list of regulated professions. An integrated corporate registration and reporting system streamlines extra-provincial business registration. In addition, dispute resolution mechanisms are timelier.

- Ontario-Quebec Trade and Cooperation Agreement (TCA): signed in 2009, this agreement aims to improve the interprovincial trade framework and enhance economic cooperation, particularly to increase harmonisation and labour mobility and improve dispute resolution. The TCA takes a positive list approach and includes chapters on economic, regulatory and energy cooperation that extend beyond traditional commitments and six sector-specific chapters that address major trade barriers. It also provides a dispute settlement mechanism that can award up to CAD 10 million in penalties for government-to-government disputes (double that in AIT) if one province is found to be inhibiting trade through the use of nontariff barriers; it does not, however, have a person-to-government dispute resolution mechanism.

- Joint Office for Regulatory and Service Effectiveness: a memorandum of understanding was signed between Nova Scotia and New Brunswick in March 2015 to build a modern, consistent and fair regulatory environment between the two provinces. The office aims at reforming regulations to reduce red tape, overlap and unnecessary regulations and reduce business costs. It also aims at making effective and efficient use of online technology and boosting provincial cooperation and harmonisation.

Another issue with the AIT in its current form is that in some cases international trade agreements allow foreign entities greater access to a province's market than is available to other provinces and territories (note that Nunavut is excluded from the current version of the AIT). To address this, the provinces and territories have agreed to the principle that the renewed AIT will adjust, where appropriate, their internal commitments with those made in international trade agreements (Council of the Federation, 2014).

Trade agreements' success depends on timely and effective enforcement, with appropriate penalties to encourage compliance. Since the AIT was signed, some amendments have led to streamlining of the dispute resolution process, the creation of appellate and compliance panels, the introduction of monetary penalties of up to CAD 5 million (amounts are proportional to each party's population) for non-compliance with dispute panel rulings, and changes to increase access to dispute resolution for private parties. Despite these changes, some challenges remain. Dispute resolution remains lengthy, averaging 41 months for those disputes that proceeded to a panel (roughly a quarter of all disputes) (Pavlovic et al., 2015). Limited penalties may reduce adherence to the rules and dispute panel findings. Furthermore, private plaintiffs must first request that the relevant government take their matter forward and can proceed alone only if the request is rejected and they pass a screening process. Rulings in their favour do not permit the private party (or government) to claim damages or allow provincial retaliation in its support (as is available for government-to-government disputes). Furthermore, there is no judicial review of decisions. While an appeals process to dispute panel decisions is available through the establishment of an appellate panel, 
compliance panel decisions cannot be appealed. Overall, to strengthen incentives for compliance with panel decisions, parties should consider raising monetary penalties and private parties should be able to claim damages. To ensure more timely resolution, private parties should have the option to carry forward a dispute against a government without first having to go through their own provincial government. Decisions should also be subject to judicial review to prevent errors of law.

Unnecessary regulatory differences may impede competition and increase costs for businesses. Regulatory reconciliation could help facilitate the movement of goods, services and labour. Mutual recognition ensures that any product or service produced or delivered in one province could be admitted into another and therefore could not be banned for sale unless there is a good reason for an exemption. Similarly, people registered to practice an occupation in one province should be entitled to practice an equivalent occupation in others, as in the 2009 amendments to Chapter 7 of the AIT relating to labour mobility for regulated professions. For instance, the NWPTA commits signatory provinces to full mutual recognition or reconciliation of their rules affecting trade, investment or labour mobility.

Internal trade agreements of other countries provide examples of the effectiveness of mutual recognition in facilitating trade and the harmonisation of regulations. The European Union has included mutual recognition measures in the Maastricht Treaty and the adoption of the Mutual Recognition Accord (MRA) in Australia obliges its constituent states to admit goods and services of other states in spite of differences in technical or quality specifications. In the Australian experience, the implementation of the MRA was successful in promoting labour mobility, contributing to wage convergence of workers across states and increasing interstate trade as a share of gross state product (Australian Government Productivity Commission, 2009). Mutual recognition is a practical and cost-effective way of overcoming incompatible regulatory regimes, which requires less bureaucracy to oversee (Macmillan, 2013). Therefore, the federal, provincial and territorial governments should consider adopting mutual recognition or other strategies for regulatory reconciliation in the updated AIT, requiring that exemptions be evidence-based.

A sharper focus (or even inserting a special chapter) on technical barriers to trade could promote more in-depth harmonisation of legislation, standards and regulations among the provinces. Furthermore, currently there are limited avenues to align internal trade agreements and regulations with corresponding international agreements. Establishing a regulatory council tasked with harmonising internal regulations between the provinces and aligning regulations in interprovincial and international agreements could help to reduce domestic trade frictions and lower business costs. For example, in Australia the Council of Australian Governments has worked to identify sectors and industries with duplication and excessive regulatory burdens (OECD, 2010, pp. 97-98). Moreover, in 2011, Canada and the United States established the Regulatory Cooperation Council to reduce red tape and make regulations more compatible, and a similar council could be beneficial for the federal, provincial and territorial governments.

To continue momentum on internal trade reform, the term of the chairperson of the Committee on Internal Trade charged with overseeing the AIT's operation and negotiating new provisions should also be extended (from the current one year) and could be supported by a federal co-chair (Canadian Chamber of Commerce et al., 2014). This would provide greater leadership and continuity within the Committee to drive reforms. In addition, a formal commitment for the Internal Trade ministers to meet more frequently than annually could also help improve collaboration and strengthen the internal market. The current practice of consensus decision-making may also be slowing progress, as provinces with protectionist interests may veto decisions. The governments could consider moving towards majority, or as in the European Union, qualified-majority voting.

Procurement by governments should be open, fair and transparent. While AIT amendments in 1999 and 2005 aimed at achieving these goals, some international trade agreements set a new benchmark (e.g., the Canada-European Union Comprehensive Economic and Trade Agreement and the World Trade 
Organisation Agreement on Government Procurement), including more favourable limits for procurement rules to apply. In addition, some Canadian sub-national internal trade agreements have gone farther in liberalising procurement than is available through the AIT (e.g. the NWPTA).

\section{Interprovincial labour mobility}

Labour mobility plays an important role in labour market adjustments in Canada, and facilitating labour reallocation could increase productivity growth (Carey, 2014). Canada's labour markets are generally dynamic and characterised by flexible employment protection legislation. Although income and employment differentials between provinces are a major factor behind interprovincial labour movements, barriers continue to exist that constrain adjustments. Efforts have been made through the AIT process to reduce barriers to labour mobility. The AIT was strengthened in 2009 with amendments that established mutual recognition of the qualifications of workers in regulated occupations. This was reinforced by the 2012 decisions covering crane operators and public accountants that held that jurisdictions cannot refuse to certify workers from another jurisdiction, unless there is demonstrable evidence of public risks, and that differences in educational standards and length of training do not by themselves constitute a reason to restrict labour mobility. However, provinces and territories continue to have the right, under certain conditions, to recommend additional requirements. Justification must be made, clearly documented and approved by the government proposing the restriction and posted publically to comply with Chapter 7 . Currently, exceptions are few relative to the number of regulated occupations.

Despite these efforts, there is evidence that provincial borders limit labour mobility (Amirault et al., 2013). For example, individuals may be concerned over having their credentials accepted in another province in an efficient and timely manner. The recent crane operators' and public accountants' settlements, which took three and ten years, respectively, have shown that such processes may be lengthy, reducing incentives for private parties to file complaints (Carey, 2014). Slow action through the AIT has also encouraged sub-national accords, as described above. Overall, governments should work together to expedite the AIT dispute resolution panel's proceedings to encourage labour mobility and compliance with the agreement. At the same time, efforts are underway through the Canadian Council of Directors of Apprenticeship to align apprenticeship systems across Canada for recognised trades to improve mobility. Moreover, Canadians' mobility is as high as in the United States, and Canada has one of the most geographically mobile labour markets in the world, suggesting that these barriers are relatively small.

\section{Sectoral interprovincial trade barriers}

Key areas where provincial sectoral barriers exist are in agriculture, securities regulation and business licencing, alcoholic beverages, ethanol blends (different ethanol blend requirements require a unique blend for each province and territory, which increases costs) and truck size and safety regulations (different weight and dimension requirements may impede businesses from working across borders). Some of these sectors are covered briefly below.

\section{Agriculture}

Despite efforts to achieve greater interprovincial trade, multiple technical and non-technical barriers remain, including the use of supply management for agricultural products. Agriculture is covered in Chapter 9 of the AIT, but its scope is limited. In November 2005, the parties agreed to expand the coverage of Chapter 9 to capture all technical measures. Additionally, some provinces and territories have enacted trade enhancement arrangements provided under Article 1800 of the AIT as an alternative way forward. In 2006, British Columbia, Alberta, Saskatchewan, Manitoba, Prince Edward Island and the Yukon signed the "Interim Agreement on Internal Trade in Agriculture and Food Goods" to expand the AIT's scope and coverage to all technical measures affecting interprovincial agriculture and food trade among the 
signatories, including health, safety, quality and labelling regulations. In applying AIT rules to Chapter 9, Article 902 of the AIT limits the unwarranted use of technical measures (e.g., technical regulations, standards) as barriers to internal trade of all agricultural and food goods - including supply-managed products - and not to prevent signatories from adopting or maintaining measures related to the functioning of the supply management system such as allocation of production or pricing mechanisms. For details on the costs of these supply management systems see Jarrett and Kobayakawa (2008).

Production- and trade-distorting agricultural support in Canada has been higher than the OECD average in recent years, mainly reflecting measures to stabilise farm incomes in the short term (OECD, 2016a). For example, the dairy quota system provides greater producer support than average in OECD countries (Figure 19, Panel A). These quotas are set to restrict the quantity of milk produced to the expected level of domestic consumption and have probably served to raise domestic dairy prices, particularly relative to the United States $(\mathrm{Li}, 2014)$. Quota elimination could help reduce Canadian prices, which are elevated compared with other OECD countries (Panel B) and could also promote more inclusive growth and innovation.

Supply management is regressive: it costs the poorest $20 \%$ of Canadians $2.3 \%$ of their incomes, relative to $0.5 \%$ for the richest $20 \%$ (Cardwell et al., 2015). It has also fragmented the production system, reducing economies of scale and the allocation of production to the most efficient producers. Annual total factor productivity growth in Canada's agricultural sector declined to 1.5\% on average in 2002-11 from $2.6 \%$ the previous decade, while the OECD average remained relatively stable around $2 \%$ over this period (OECD, 2016a), likely reflecting in part weakened incentives resulting from these supply management policies. While a small increase in dairy imports can be expected through the implementation of the TransPacific Partnership, a broader phasing out of supply management policies would lead to more significant improvements in inclusive growth.

Figure 19. Dairy producer support and prices

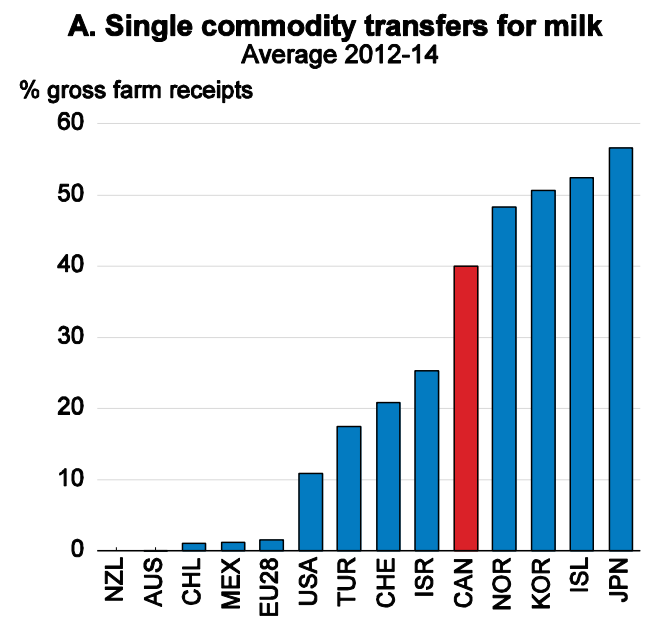

\section{B. Canadian consumer prices for dairy and eggs are high} In PPP terms, index OECD = 100, 2011

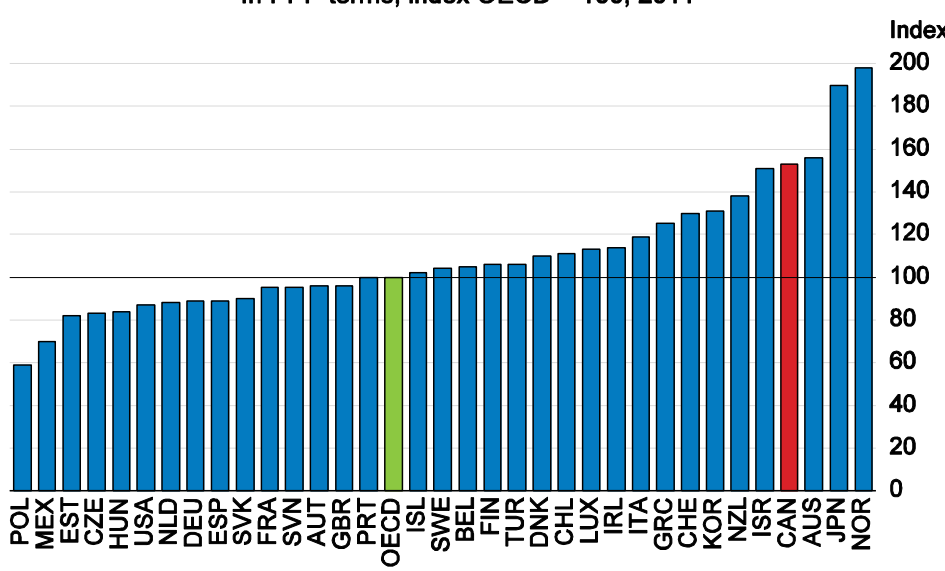

Source: OECD, Agricultural Policy Indicators - Producer and Consumer Support Estimates and Purchasing Power Parities Statistics databases.

\section{Alcoholic beverages}

Although alcoholic beverages are covered under Chapter 10 of the AIT, it deals only with fees and discriminatory listing of products. Moreover, while amendments to the Importation of Intoxicating Liquors Act removed federal restrictions on the shipment of wine across provincial borders in 2012 and beer and spirits in 2014, significant provincial and territorial barriers continue to exist. As a result, wineries and 
breweries looking to expand across provincial or territorial borders experience some obstacles, as alcohol generally cannot be sold directly to consumers in other provinces. This reduces consumer choice and lowers revenues for Canadian wineries and breweries. To date, only British Columbia, Manitoba and Nova Scotia have lifted some of their restrictions on the interprovincial movement of alcohol.

Alcohol retailing in some provinces is subject to a low level of competition due to strict regulation. While Alberta privatised liquor retailing beginning in 1993, liquor authorities in many other provinces continue to play a large role in retailing. In Ontario, for instance, the Liquor Control Board of Ontario, which is government owned, has near exclusive rights to sell wine and spirits, and The Beer Store, owned by three major breweries, does most of the retailing of beer in the province. Two large provincial wineries also have the right to sell their wines in major off-winery stores, but no such access is provided for most other wineries. Recent reforms have eased restrictions on beer sales, however, as selected supermarkets are now permitted to sell beer at regulated prices, with a requirement that at least $20 \%$ of shelf space be allocated to smaller brewers to promote market access for small players. Recent reforms aside, the lack of competition in Ontario's system is estimated to increase costs for consumers and secondary distributors like restaurants (given price discrimination for resale to commercial establishments) and may reduce government revenues, particularly when compared to more liberalised provinces (Masson and Sen, 2014). Progress to encourage competition in other provinces is generally further advanced. For instance, since 2002 British Columbia has allowed privately owned retail outlets to co-exist with government-owned stores, and Quebec has allowed the sale of wine and beer in grocery and convenience stores, while the crown corporation Societé des alcools du Québec remains present in spirits and wine retailing.

\section{Securities regulation}

Canada is the only OECD country without a national securities regulator. While support for its creation from the federal government is longstanding, the Supreme Court unanimously rejected a federal proposal in 2011 on the grounds that it overstepped trade and commerce provisions in the constitution, where securities regulation falls within the property and civil rights power assigned to the provinces. The current fragmented structure of provincial regulators leads to duplication and overlap, resulting in a likely misallocation of resources, and may make it difficult for securities regulators to react quickly and decisively to capital market events (EPSR, 2009). Furthermore, market participants may be plagued with undue compliance costs by having to pay fees in up to 13 separate jurisdictions.

Some progress has been made in harmonising capital markets regulation across provinces, despite the lack of a national regulator. British Columbia, New Brunswick, Ontario, Prince Edward Island, Saskatchewan, Yukon and the federal government have agreed to establish a cooperative regulator (Cooperative Capital Markets Regulatory System) to harmonise and modernise capital markets regulation in their jurisdictions. Administration of the resulting provincial and federal acts will be delegated to a common regulator, the Capital Markets Regulatory Authority. The federal government should continue to work with the remaining provinces and territories to foster broader participation in this system to encourage more efficient securities regulation, while maintaining a strong regional regulatory presence throughout Canada.

\section{Corporate registration}

Canada also has a decentralised corporate registration and reporting regime, and the different approaches taken by the provinces increase business costs, particularly for SMEs. Despite commitments made in the AIT (Annex 606) to adopt a Standard Statement of Registration, the sharing of information among provinces (by the home province) and the simplification of annual filings, further nationwide progress in this direction would be beneficial. Harmonising and streamlining reporting requirements and creating a one-stop shop for registration could facilitate business expansion and increase competitiveness 
by reducing costs. While the direct costs of the current fragmented system are probably moderate, in the low-to-mid tens of millions of Canadian dollars annually (Schwanen and Chatur, 2014), these requirements may add additional barriers for small businesses looking to expand across borders, for which these costs may be more significant as a share of revenues, thereby lowering productivity through reduced business scale. The scaling up of small businesses is a key challenge in Canada and is covered in more detail in Carey et al. (2016).

Despite the currently fragmented system, progress has been made to streamline requirements across some regions. Nova Scotia and New Brunswick moved the furthest in this direction in 1994 by agreeing to mutual recognition, thereby requiring corporations to register only in one province to conduct business in the other. Through the 2013 amendments to the NWPTA these frictions have also been reduced between British Columbia, Alberta and Saskatchewan by providing companies registering in one of these provinces assistance in registering in partner provinces, and annual reports and registration fees need to be filed and paid in only one province. In 2004 Canada also implemented a Joint Online Registration System, which is recognised in Newfoundland, Nova Scotia, Ontario and Saskatchewan, which provides federally incorporated companies registering in one of these provinces technical assistance to register in the others. While these initiatives have moved part way to achieving the original AIT goals, they remain fragmented regionally, and some suffer from a lack of information sharing (Nova Scotia and New Brunswick agreement) and of harmonisation of information requirements (NWPTA and the Joint Online Registration System).

Canada is also lagging best international practice in this area. Australia and Switzerland, for instance, have moved to harmonise or integrate their business registries to improve the functioning of their internal markets. In Australia, for instance, a national registrar (the Australian Business Register) has existed since 2012, while in Switzerland registration is required in only one canton to do business in others. To improve competitiveness and reduce administrative costs, provincial governments should harmonise information requirements and sharing, implement the mutual recognition of annual reporting requirements, as envisioned in the AIT, and investigate the costs and benefits of implementing a national registry.

Recommendations to reduce interprovincial barriers to trade and labour mobility
- $\begin{aligned} & \text { Broaden the AIT's coverage as much as possible, including by adopting a negative-list approach to } \\ & \text { trade negotiation (from the current positive-list approach). }\end{aligned}$
- Adopt mutual recognition in the updated AIT, requiring that exceptions be evidence-based, and move
towards regulatory harmonisation by establishing a national regulatory cooperation council.
- Automatically extend more favourable provisions granted to foreign countries to other provinces in the
updated AIT.
Take measures to ensure compliance with the AlT and its panel reports, including by raising monetary
penalties and enabling private parties to claim damages. To ensure more timely resolution, allow
private parties to launch proceedings, without first having to go through their provincial governments,
and expedite dispute resolution. All decisions should be subject to judicial review.
Abolish supply management in dairy, eggs and poultry, and liberalise alcohol trade and retailing.
Encourage remaining provinces to join the Cooperative Capital Markets Regulatory System, while
maintaining a strong regional presence throughout Canada.
Move towards a national corporate registration system.




\section{Regulatory and institutional measures to encourage competition}

Effective regulation is essential to achieve policy objectives with respect to efficiency and economic growth. Canada remains amongst the best performers with regards to regulatory practices. It has adopted formal requirements for stakeholder engagement, ex ante regulatory impact assessment and ex post evaluation of primary laws and subordinate regulations in its policy processes and implemented them. As a result, it ranks highly in each of these domains relative to other OECD countries (OECD, 2015c; Figure 20).

\section{Figure 20. Indicators of regulatory policy and governance ${ }^{1}$}

A. Regulatory Impact Assessment (RIA)

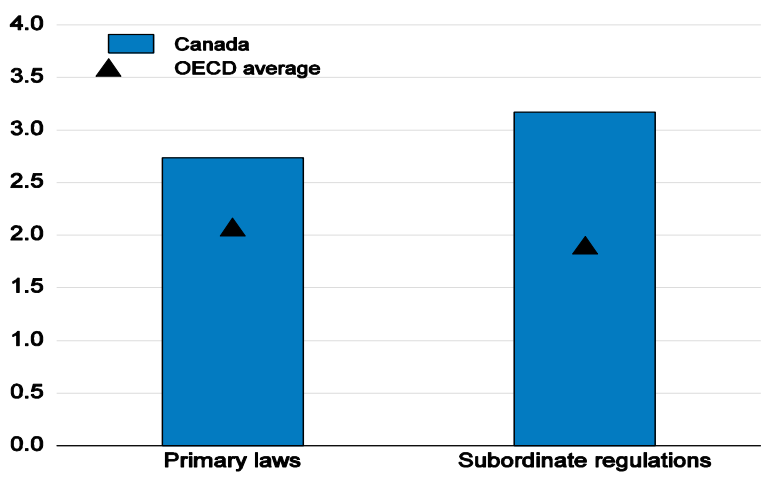

C. Stakeholder engagement for developing regulations

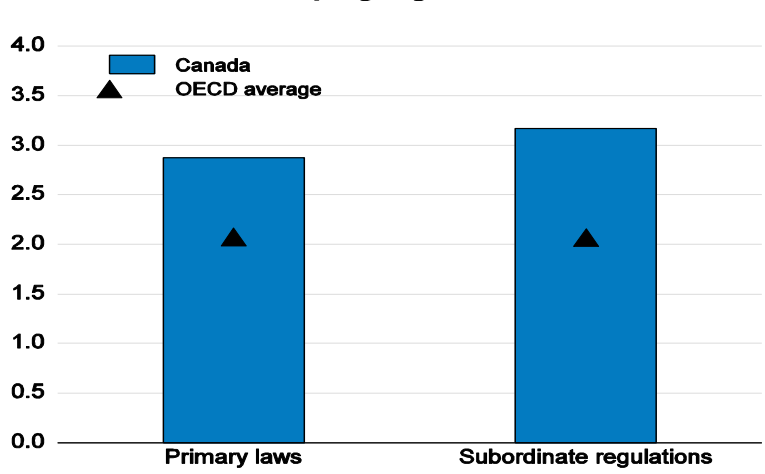

B. Ex post evaluation of regulations

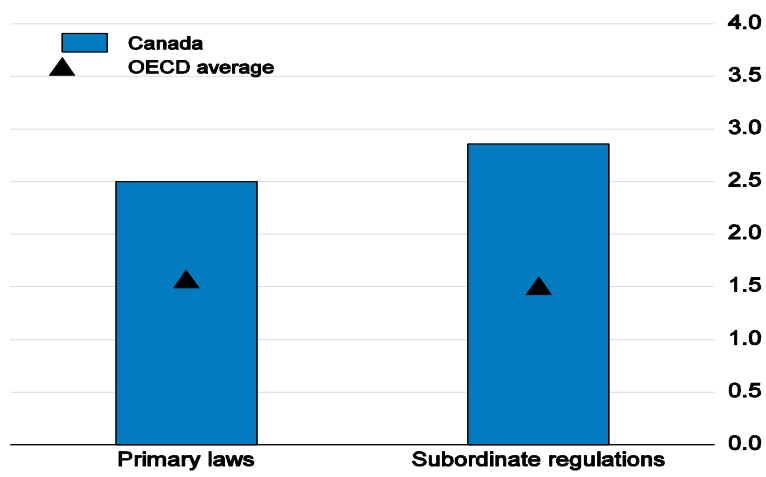

D. Share of primary laws covered by the indicators

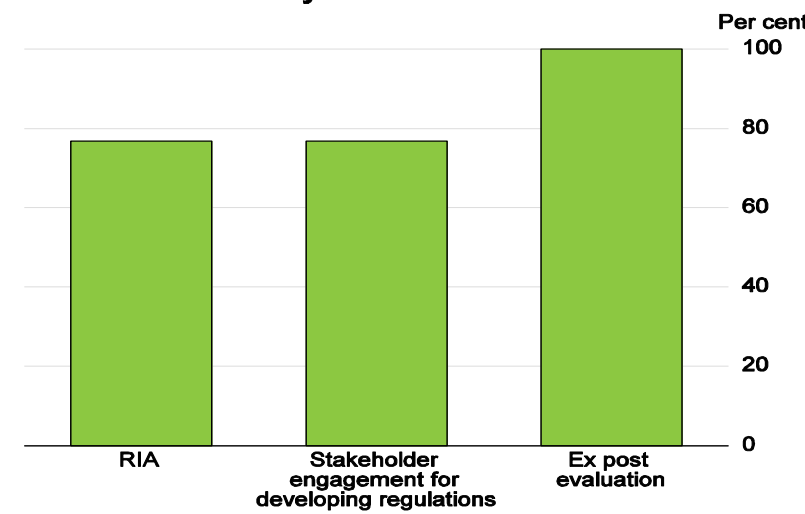

1. The figures display the aggregated scores from all four categories giving the total composite score for each indicator. The maximum score for each aggregated indicator is four.

Source: OECD (2015), Regulatory Policy Outlook, www.oecd.org/regreform/regulatory-policy/.

One area where Canada could benefit is in the extension of public advocacy powers and market studies for the federal competition authorities whereby they are granted the power to require provision of relevant information in the context of conducting such studies (OECD, 2016a). This would strengthen their ability to examine and publicly report on government policy, regulations or market participant behaviour that may inhibit competition. Many OECD countries have benefited from having such prerogatives, which can enhance transparency and openness in the policymaking process, enabling a more informed public discussion of a particular issue or industry's performance. They also provide governments at all levels with an understanding of how their current or proposed regulations may impact industry structure, consumers and, in the long term, economic growth. These powers are more effective when supplemented by a requirement for government entities subject to recommendations to provide a written response within a fixed time period, as is done in the United Kingdom. 
ECO/WKP(2016)46

\section{Recommendations for institutional measures to enhance competition}

- $\quad$ Grant the Competition Bureau the power to require provision of relevant information in the context of conducting market studies and advocacy activities. Require federal government agencies to "comply or explain" in response to the Bureau's recommendations. 


\section{Bibliography}

Albrecht, L. and T. Tombe (2016), "Internal Trade, Productivity, and Interconnected Industries: A Quantitative Analysis", Canadian Journal of Economics, Vol. 49, Issue 1, forthcoming.

Andrews, D., C. Criscuolo and P. Gal (2015), "Frontier Firms, Technology Diffusion and Public Policy: Micro Evidence from OECD Countries", The Future of Productivity: Main Background Papers, OECD Publishing, Paris.

Amirault, D., D. de Munnik and S. Miller (2013), "Explaining Canada's Regional Migration Patterns", Bank of Canada Review, Spring, pp. 16-28.

Australian Government Productivity Commission (2009), "Review of Mutual Recognition Schemes", Productivity Commission Research Report, January.

Borenstein, S. and J. Bushnell (2015), "The US Electricity Industry After 20 Years of Restructuring", Annual Review of Economics, Vol. 7, pp. 437-63, August.

Brennan, T. (2008), "Generating the Benefits of Competition: Challenges and Opportunities in Opening Electricity Markets", C.D. Howe Institute Commentary, No. 260, April.

Cairns, M. (2015), "Staying on the Right Track: A Review of Canadian Freight Rail Policy", MacdonaldLaurier Institute Publication, February.

Canadian Chamber of Commerce et al. (2014), "A New Vision for Interprovincial Trade in Canada: A Business Agenda for Strengthening Canada's Economic Union", a letter to the Council of the Federation, 6 August, http://www.cga-canada.org/en-ca/LettersToTheGovernment/ca_ltr_2014-0806 internal-trade.pdf.

Canadian Transportation Act Review Panel (CTARP) (2001), Vision and Balance: Report of the Canadian Transportation Act Review Panel, June.

Canadian Transportation Act Review Secretariat (CTARS) (2015), Pathways: Connecting Canada's Transportation System to the World, Vol. 1, December.

Canadian Transportation Agency (CTA) (2014), Regulations Amending the Railway Interswitching Regulations, July, http://www.gazette.gc.ca/rp-pr/p2/2014/2014-08-13/html/sor-dors193-eng.php.

Cardwell, R., C. Lawley, and D. Xiang (2015), "Milked and Feathered: The Regressive Welfare Effects of Canada's Supply Management Regime”, Canada Public Policy, Vol. 41, March.

Carey, D. (2014), "Overcoming Skills Shortages in Canada", OECD Economics Department Working Papers, No. 1143, July, OECD Publishing, Paris.

Carey, D., J. Lester and I. Luong (2016), "Boosting Productivity through Greater Small Business Dynamism in Canada", OECD Economics Department Working Papers, No. 1314, July, OECD Publishing, Paris.

Canadian Broadcasting Corporation (CBC) (2015), CRTC Eases Canadian-Content Quotas for TV, 12 March, http://www.cbc.ca/news/business/crtc-eases-canadian-content-quotas-for-tv-1.2992132. 
Council of the Federation (2014), Premiers Will Lead Comprehensive Renewal of Agreement on Internal Trade, 29 August, http://www.canadaspremiers.ca/phocadownload/newsroom_2014/internal_tradefinal.pdf.

Canadian Pacific Consulting Services (CPCS) (2014), "Evolution of Canadian Railway Economic Regulation and Industry Performance under Commercial Freedom", report by CPCS Transcom Ltd. prepared for the Railway Association of Canada, November.

Canadian Radio-Television and Telecommunications Commission (CRTC) (2015), CRTC Communications Monitoring Report, October.

Dachis, B. (2014), "Full Throttle: Reforming Canada's Aviation Policy", C.D. Howe Commentary, No. 389, January.

Denk, O. (2016), "How Policy Reforms Affect Workers: Evidence from the Deregulation of Network Industries", OECD Economics Department Working Papers, forthcoming.

Dewing, M. (2011), “Canadian Broadcasting Policy”, Library of Parliament Background Papers, June.

Distributed Energy Financial Group (DEFG) (2015), Annual Baseline Assessment of Choice in Canada and the United States, July.

Elixmann, D., I. Godlovitch, I. Henseler-Unger, R. Schwab and U. Stumpf (2015), Competition and Investment: An Analysis of the Drivers of Investment and Consumer Welfare in Mobile Telecommunications, July.

Emera (2014), "Emera Demonstrates Benefit of Federal Loan Guarantee for Nova Scotia Electricity Consumers", http://www.emeranl.com/en/home/newsinformation/newsannouncements/Loan Guarantee.aspx.

Expert Panel on Securities Regulation (EPSR) (2009), Final Report and Recommendations, January.

Federal Reserve Bank of San Francisco (FRBSF) (2002), "Competition and Regulation in the Airline Industry”, FRBSF Economic Letter No. 2002-01, January.

Gill, V. (2012), "Driven Away: Why More Canadians are Choosing Cross Border Airports”, Conference Board of Canada, October.

Goulding, A. (2013), “A New Blueprint for Ontario's Electricity Market”, C.D. Howe Institute Commentary, No. 389, September.

Government of Newfoundland and Labrador (2013), "Investing in Muskrat Falls for an Energized Economy", http://www.releases.gov.nl.ca/releases/2013/exec/1210n05.htm.

Henton, D. (2015), "Regulator Finds TransAlta Breached Rules in Power Price-Fixing Case”, The Calgary Herald, 27 July.

Hummels, D. and G. Schaur (2013), "Time as a Trade Barrier", American Economic Review, Vol. 103, December.

International Energy Agency (IEA) (2007), Tackling Investment Challenges in Power Generation, OECD Publishing, Paris. 
IEA (2016), Energy Policies of IEA Countries: Canada 2015, OECD Publishing, Paris, http://dx.doi.org/10.1787/9789264243644-en

International Transportation Forum (ITF) (2014), "What is Rail Efficiency and How Can It Be Changed?", International Transportation Forum Discussion Paper, No. 2014-23, November.

InterVISTAS Consulting (2003), An Economic and Regulatory Framework for Rail Competitiveness, March.

Ivaldi, M. and G. McCullough (2004), "Subadditivity Tests for Network Separation with an Application to US Railroads", CEPR Discussion Paper, No. 4392, May.

Jarrett, P. and S. Kobayakawa (2008), "Modernising Canada's Agricultural Policies", OECD Economics Department Working Papers, No. 629, OECD Publishing, Paris.

Kemp, A. (2014), “Why Aren't Albertans Taking Advantage of the Deregulated Electricity Market?", Alberta Venture, 21 January.

Koske, I., I. Wanner, R. Bitetti and O. Barbiero (2015), "The 2013 Update of the OECD's Database on Product Market Regulation - Policy Insights for OECD and Non-OECD Countries", OECD Economics Department Working Papers, No. 1200, OECD Publishing, Paris, http://dx.doi.org/10.1787/5js3f5d3n2vl-en

Li, N. (2014), "Sticker Stock: The Causes of the Canada-US Price Differential", C.D. Howe Commentary, No. 409, May.

Madas, M. and K. Zografos (2010), “Airport Slot Allocation: A Time for Change?”, Transport Policy, Vol. 17, pp. 274-85, August.

Masson, P. and A. Sen (2014), "Uncorking a Strange Brew: The Need for More Competition in Ontario's Alcoholic Beverage Retailing System”, C.D. Howe Commentary, No. 414.

McKitrick, R. and T. Adams (2014), "What Goes Up... Ontario's Soaring Electricity Prices and How to Get Them Down", Fraser Institute, October.

MacMillan, K. (2013), A Comparison of Internal Trade Regimes: Lessons for Canada, September.

Nordås, H. K. and D. Rouzet (2015), "The Impact of Services Trade Restrictiveness on Trade Flows: First Estimates", OECD Trade Policy Papers, No. 178, OECD Publishing, Paris.

OECD (2004), OECD Economic Surveys: Canada, OECD Publishing, Paris.

OECD (2005), "Competition Issues in the Electricity Sector", OECD Journal: Competition Law and Policy, Vol. 6/4, OECD Publishing, Paris, http://dx.doi.org/10.1787/clp-v6-art11-en

OECD (2010), OECD Economic Surveys: Australia, OECD Publishing, Paris.

OECD (2011), "Next Generation Access Networks and Market Structure", OECD Digital Economy Papers, No. 183, OECD Publishing, Paris, http://dx.doi.org/10.1787/5kg9qgnr866g-en 
OECD (2013), Recent Developments in Rail Transportation Services, OECD Publishing, Paris, http://www.oecd.org/daf/competition/Rail-transportation-Services-2013.pdf.

OECD (2014a), “Airline Competition”, June http://www.oecd.org/officialdocuments/publicdisplaydocumentpdf/?cote=DAF/COMP(2014)14\&do cLanguage $=$ En .

OECD (2014b), “Airline Competition: Note by Canada”, June, http://www.oecd.org/officialdocuments/publicdisplaydocumentpdf/?cote=DAF/COMP/WD(2014)34 \&docLanguage $=$ En.

OECD (2014c), The Governance of Regulators, OECD Best Practice Principles for Regulatory Policy, OECD Publishing, Paris, http://dx.doi.org/10.1787/9789264209015-en

OECD (2014d), "Wireless Market Structures and Network Sharing", OECD Digital Economy Papers, No. 243, OECD Publishing, Paris, http://dx.doi.org/10.1787/5jxt46dz19r2-en

OECD (2015a), Being an Independent Regulator: The Why and the How, GOV/RPC/NER(2015)4.

OECD (2015b), OECD Digital Economy Outlook 2015, OECD Publishing, Paris, http://dx.doi.org/10.1787/9789264232440-en

OECD (2015c), OECD Regulatory Policy Outlook 2015, OECD Publishing, Paris, http://dx.doi.org/10.1787/9789264238770-en

OECD (2016a), Canada, Better Policy Series Brochure, forthcoming.

OECD (2016b), OECD Economic Surveys: Canada 2016, OECD Publishing, Paris, http://dx.doi.org/10.1787/eco_surveys-can-2016-en

Ontario Energy Board (OEB) (2015), "Regulated Price Plan - Price Report November 1, 2015 to October 31, 2016", October.

Pavlovic, M., J. Bishop and P. Holdsworth (2015), Dispute Resolution in Agreement on Internal Trade: A Consumer Perspective, Public Interest Advocacy Centre, Ottawa.

Pineau, P-O. (2008), "Electricity Subsidies in Low-Cost Jurisdictions: The Case of British Columbia", Canadian Public Policy Vol. 34, pp. 379-94, September.

Pineau, P-O. (2013), "Fragmented Markets: Canadian Electricity Sectors' Underperformance", in Evolution of Global Electricity Markets, Elsevier, London.

Prentice, B. and G. Parsons (2015), Freedom in Western Grain Movement, January.

Public Policy Forum (2013), Canada's Evolving Internal Market: An Agenda for a More Cohesive Economic Union, October.

Rouzet, H. and D. Spinelli (2015), "Services Trade Restrictiveness, Mark-ups and Competition", TAD/TC/WP(2015)21. 
Schulman, J. (2014), "Proposed Changes to Interswitching Regulations in Bill C-30 Raise Many Questions", Canadian Transportation Research Forum, April.

Schwanen, D. and O. Chatur (2014), "Registering in Harmony: The Case for Pan-Canadian Corporate Registration", C.D. Howe E-Brief, No. 171, February.

Sen, A. (2015), "Peak Power Problems: How Ontario's Industrial Electricity Pricing System Impacts Consumers", C.D. Howe E-Brief, No. 209, June.

Standing Senate Committee on Transport and Communications (SSCTC) (2012), The Future of Canadian Air Travel: Toll Booth or Spark Plug?, June.

Transport Canada (2014), Transportation in Canada 2014: Statistical Addendum, April.

Transport Canada (2015), The Blue Sky Policy: Made in Canada for Canada, https://www.tc.gc.ca/eng/policy/air-bluesky-menu-2989.htm (accessed 6 July 2015).

Wall Communications Inc. (2015), Price Comparisons of Wireline, Wireless and Internet Services in Canada and with Foreign Jurisdictions, March. 